IZA DP No. 5961

Why Are So Few Females Promoted into

CEO and Vice-President Positions?

Danish Empirical Evidence 1997-2007

Nina Smith

Valdemar Smith

Mette Verner

September 2011 


\title{
Why Are So Few Females Promoted into CEO and Vice-President Positions? Danish Empirical Evidence 1997-2007
}

\author{
Nina Smith \\ Aarhus University, CIM \\ and IZA \\ Valdemar Smith \\ Aarhus University, CIM, GLOBID \\ Mette Verner \\ Danish School of Media and Journalism \\ and CIM \\ Discussion Paper No. 5961 \\ September 2011 \\ IZA \\ P.O. Box 7240 \\ 53072 Bonn \\ Germany \\ Phone: +49-228-3894-0 \\ Fax: +49-228-3894-180 \\ E-mail: iza@iza.org
}

\begin{abstract}
Any opinions expressed here are those of the author(s) and not those of IZA. Research published in this series may include views on policy, but the institute itself takes no institutional policy positions.

The Institute for the Study of Labor (IZA) in Bonn is a local and virtual international research center and a place of communication between science, politics and business. IZA is an independent nonprofit organization supported by Deutsche Post Foundation. The center is associated with the University of Bonn and offers a stimulating research environment through its international network, workshops and conferences, data service, project support, research visits and doctoral program. IZA engages in (i) original and internationally competitive research in all fields of labor economics, (ii) development of policy concepts, and (iii) dissemination of research results and concepts to the interested public.
\end{abstract}

IZA Discussion Papers often represent preliminary work and are circulated to encourage discussion. Citation of such a paper should account for its provisional character. A revised version may be available directly from the author. 


\begin{abstract}
Why Are So Few Females Promoted into CEO and Vice-President Positions? Danish Empirical Evidence 1997-2007

In most OECD countries, only very few women succeed in reaching top executive positions. In this paper, the probability of promotion into VP and CEO positions is estimated based on employer-employee data on all Danish companies observed during the period 1997-2007. After controlling for a large number of family-related variables, including take-up history of maternity and paternity leave and proxies for 'female-friendly' companies, there is still a considerable gap in the promotion probabilities for CEO positions, but not for VP positions. Thus, the results cannot confirm recent theories on 'belief flipping' or disappearance of statistical discrimination against women who succeed getting into career track positions. The results reflect that the hiring decision and the decision to enter a top position as 'number one', i.e. CEO, in the organization is very different from the decision to hire or become VP, i.e. 'number two' or lower.
\end{abstract}

JEL Classification: $\quad$ G34, J16, J24, M51

Keywords: promotion, top executive positions, statistical discrimination

Corresponding author:

Nina Smith

School of Economics and Management

Aarhus University

Bartholins Allé 10

Building 1326

DK-8000 Aarhus C

Denmark

E-mail: nsmith@econ.au.dk

\footnotetext{
* Thanks to participants at the ESPE conference in Essen (2010) and seminar participants at department of economics at University of Lund and University of Essex for helpful comments to an earlier version of the paper. Joachim Borg Kristensen and Kasper Granild have been extremely helpful as research assistants on the project.
} 
"I have got my life back", Stine Bosse, former female CEO of TRYG-VESTA, one of the largest Scandinavian insurance companies. Interview in a Danish newspaper (Berlingske) April 2011, a few months after she left the position as CEO of one of the largest Danish listed companies, TRYG-VESTA

\section{Introduction}

The main motivation for this study on promotion into top executive positions is the fact that women constitute a very small proportion of CEOs in most OECD countries, despite the fact that women in many countries are as educated as their male peers and also have been active labour market participants during the latest decades. In Denmark, only $7 \%$ of the CEOs in companies with more than 50 employees are women, and for the other Scandinavian countries the picture is about the same. Restricting to larger companies, the proportion of women among CEOs is even smaller. Since Danish women were - jointly with other Nordic women - among the first in the Western world to enter the labour market during the 1960s and 1970s, these figures may at first glance be surprisingly low. Furthermore, the fact that women are increasingly improving on e.g. educational attainment and males are increasingly taking part in care for children and household work in general would suggest that the promotion chances of women relative to men should have increased considerably over time. Also, there has been an increasing focus in the management literature on the advantages of diversity management, which might have induced firms to increase the share of women in the executive teams and on the boards in general.

A few years ago, Denmark and other Scandinavian countries were nominated as forerunners with respect to equal opportunities and family-friendly policies in a number of OECD country studies published under the title 'Babies and Bosses, Reconciling work and family life', see OECD (2002, 2003, 2004, 2005). The Scandinavian countries were praised by OECD for having been able to maintain a fairly stable fertility rate during the latest decades when Scandinavian women entered the labour market and became full time workers. Denmark is ranked as number 7 (of 134 countries) on the overall "Gender Gap Index", see World 
Economic Forum (2010). However, when it comes to the representation of women in top positions in the labour market, the Scandinavian countries are not forerunners. Denmark is ranked as low as no. 68 with respect to the gender gap for representation among "legislators, senior officials and managers".

This paper analyzes the question why so few women succeed in becoming promoted into top executive positions as CEOs or Vice-Presidents in a Nordic country, Denmark? Are there still discriminatory forces working against women, either through classical discriminatory mechanisms or via more subtle mechanisms like imperfect information and statistical discrimination, giving rise to the same outcomes as classical discrimination, but working via different channels and for different reasons? Alternatively, another hypothesis is that the observed and apparent "glass-ceiling" may partly be explained by observed and unobserved differences with respect to career decisions, preferences, characteristics and risk behavior of male and female managers. In particular, we investigate whether observed behavior with respect to timing of childbirths, periods out of the labour market, and choice of partner and spouse can explain the gender gap and whether these potential effects vary across the career ladder and are strongest at the top?

This study tests two recent dynamic models of statistical discrimination in promotion, originally proposed by Fryer (2007) and Bjerk (2008). The model by Fryer predicts that women may face statistical discrimination and higher hiring standards at a lower level on the career ladder, but if they succeed in becoming promoted into high-level executive positions, 'belief flipping' may happen, i.e. women may face 'inverse discrimination' because employers know they were selected from the top of the ability distribution. Contrary to Fryer, Bjerk's model predicts that there is no gender gap in promotions at the highest levels in the organization. In this paper, we focus explicitly on the upper levels: The promotion from a (high) executive position into a Vice-President position (VP) and the promotion from VP to Chief Executive Officer (CEO). The model is estimated on a Danish employer-employees sample of top executives and potential top executives observed during the period 1996-2007 covering all Danish private or listed companies with more than 50 employees. The probability models are estimated by panel logit models.

The novelty of this paper is that we apply a model of statistical discrimination on the narrow top 
positions as VP and CEO and estimate the model on a large panel sample which covers all Danish companies with more than 50 employees in the private sector. The large sample allows us to dig more deeply into the relation between the promotion of female top executives and childbirths, maternal leave periods out of the labor market, the careers of spouses, and the gender composition of the management board and board of directors. We present new empirical evidence on the paradox that there still exists a considerable gender gap or glass ceiling at the top of the Danish labor market despite the fact that it is now more than a half century since Danish women entered the labor market, despite of more decades with family-friendly policies, and despite the fact that women are now more educated than men and constitute a majority at universities.

Our results indicate that when controlling for a large number of observed and unobserved timeinvariant firm and individual characteristics, there is still a significant gender gap in promotion rates into VP and CEO positions. Child-related variables as number of children and take-up of maternity leave in the past and variables reflecting whether the firms are expected to have a 'female friendly' recruitment policy have significantly different coefficients for male and female executives in the estimated promotion functions, but even allowing for gender-specific coefficients for these variables, we are not able to reduce the 'unexplained gap', i.e. the coefficient of the gender indicator to insignificance. We find empirical evidence that the promotion processes into VP positions are different from promotion into CEO positions, conditional of having reached a VP position. But we cannot confirm an a priori hypothesis that statistical discrimination effects are more pronounced for promotions into VP positions than for promotion into CEO positions. We tend to find the opposite. Thus, we cannot confirm recent theories on the existence of 'belief flipping' or disappearance of statistical discrimination against women who succeed in getting into career track positions. The results reflect that the hiring decision and the decision to enter a top position as 'number one', i.e. CEO, in the organization is very different from the decision to hire or become VP, i.e. 'number two' or lower. Our results indicate that gender differences in preferences with respect to top positions may interact with statistical discrimination mechanisms in a complex way. 


\section{Earlier Studies and Empirical Evidence}

One of the first economic models on the gender gap in promotion is presented in Lazear and Rosen (1990). Their model predicts a glass ceiling in promotion rates for women without assuming any taste-based discrimination among employers and assuming similar job ability distributions for men and women. The driving assumption is that women are superior to men in the ability of non-market work, e.g. housework and care for children, and therefore have a higher probability of leaving the job as the non-market alternative is more likely to exceed the wage offer. The model predicts that women must have higher abilities than men to become promoted and therefore, on average, are less likely to be promoted. Booth et al. (2003) use the concept 'sticky floors' as an alternative explanation of the few women observed at the top of the hierarchy. 'Sticky floors' refers to a process where women are promoted to the same extent as their male colleagues but experience a slower subsequent compensation growth upon promotion. If female executives are less flexible compared to men (because of obligations at home, they may not be able to commute long distances, the family may be less willing to move because of new job opportunities of the mother etc.), they may have less favorable outside opportunities, i.e. they are not able to be promoted by getting a better job in another company to the same extent as their male colleagues. Their current employer may be aware of this fact and may exploit it by offering lower wages to female executives.

A few recent papers aim at explaining the existence of a glass ceiling as an equilibrium outcome in a dynamic model, see Fryer (2007) and Bjerk (2008). These models build on the assumption that women either have a higher turnover rate (due to childbirth-related career interruptions) or they are less able to signal their skills for different reasons compared to their male peers, i.e. the models are basically variants of the statistical discrimination theory, originally proposed by Phelps (1972). Bjerk's model may be considered a synthesis of glass ceiling and sticky floor models in the sense that both effects can coexist. Statistical discrimination against women is explained by the fact that the majority of those making promotion decisions are men and this fact 'explains' why women have more difficulties in signalling their

productivity as effectively or/and as frequently as their male counterparts. According to the model in 
Bjerk (2008), female executives face statistical discrimination at lower levels, but for those women who succeed in getting into a career track there is no statistical discrimination. In the model by Fryer (2007), female executives even face 'belief flipping' implying that they have higher promotion rates to higher level positions than their male peers.

In the sociological and management literature, a parallel theory to the economic statistical discrimination models and 'belief theories' has been the 'gender stereotyping models'. One hypothesis is the 'Think Manager-Think Male' hypothesis which says that there is a tight relation between sex role stereotypes and the characteristics which are necessary in order to become a successful manager, see Schein (1973). I.e. employers, colleagues and even the potential top executives themselves, whether males or females, tend to have gender stereotype views on what it takes to hold a position as a CEO. This may give rise to the (statistical) discrimination effects described above, or it may keep women away from applying for top executive positions because they find them more unattractive and more difficult to combine with a good life than comparable men do. Women may feel they have to give up a 'normal life' if they shall fill the role as a CEO.

Another explanation of the low proportion of female top executives is that women do not want to take the risk and responsibilities related to top executive jobs, see e.g. Booth and Nolen (2009) and Niederle and Vesterlund (2007). Niederle and Vesterlund show that women are more reluctant to engage in a competitive tournament incentive scheme than their male counterparts, even though female ability and performance equalize male ability and performance. Women may dislike competition more than men or they may be less self-confident than men with respect to their own abilities. According to the experiments in Niederle and Vesterlund, it is mainly the latter effect which explains why women 'shy away' from competition. If men and women possess different behavior with respect to applying for top executive positions, these differences may enhance the observed gender gap in promotion probabilities at lower levels in the hierarchy as predicted in the models by Fryer and Bjerk. But they may reverse the predictions concerning the gender gap at top level promotions if women are more reluctant to apply for 
positions at the highest level, i.e. CEO positions, because of different preferences or less confidence on own abilities.

The empirical results concerning gender differences in promotion rates (defined more broadly, i.e. not restricted to CEO positions) are mixed, see for instance Blau and DeVaro (2006). When controlling for other observed factors, some studies find that women are less likely to get promoted in private firms, see for instance McCue (1996), Cobb-Clark (2001), Blau and DeVaro (2006), and Frederiksen and Kato (2011). However, other studies do not confirm this pattern. Booth et al. (2003) find that women are promoted to about the same extent as men, but they do not get as high wage growth after promotion as men (the 'sticky floor' result). The influence of personal traits is investigated empirically by Fietze et al.(2009) who find that German men seem to be more willing to take risks compared to women, but according to this study these personal traits cannot explain much of the gender gap with respect to occupational positions in Germany. Bell (2005) finds that promotion chances of female executives are significantly higher in women-led firms in the US. I.e. there is a positive effect of female CEOs or female board chairmen on the salaries and promotion rates of female managers at lower levels in the firm.

Blau and DeVaro (2006) include the gender of the supervisor when explaining promotion into higher ranking positions and do not find any effect of the gender of the supervisor. As they note, this does not rule out the possibility of gender discrimination against females in executive positions if female supervisors also have prejudices against women subordinates - sometimes denoted the 'Queen Bee Syndrome'. This hypothesis is actually confirmed by Neergaard et al. (2008) who find that Danish managers have a fairly stereotype perception of what it takes to become a successful manager. The most surprising finding in their study is that it is mainly female managers who have very gender stereotype views on what it takes to become a successful manager, while male managers are much more gender neutral in Denmark!

There are very few empirical studies on the gender gap in promotion rates at the highest level, i.e. CEO level, in the company, but a few empirical studies have analyzed the compensation gap among CEOs. In the seminal study by Bertrand and Hallock (2001) on the earnings of US CEOs, the 'raw' compensation 
gap between male and female top executives was estimated to be $44 \%$, but when controlling for differences in observed characteristics, most of the gender compensation gap disappeared, i.e. it was 'explained' by observed factors. For Denmark, a recent study by Smith et al. (2011) also documents that occupational position is a very important determinant of gender compensation differentials among top executives. To our knowledge, the only other paper analyzing the gender gap in promotion of CEOs is the paper by Matsa and Miller (2011). They find that the female share of board of directors has a significantly positive effect on the female share of top management (top 5 positions) in US S\&P companies during the period 1997-2009.

\section{Theoretical Framework}

The model applied in this study builds on the model in Bjerk (2008). We assume that in a career track for top executives there are two steps to the top: A potential top executive may be promoted from the Pool of Potentials (POP) into the position as a Vice-President (VP). There may be more than one VP in a given company. CEOs are selected among the VPs in the firm concerned or recruited among VPs outside the firm. ${ }^{1}$ There are two types of workers in the POP group: $h$-workers who are high-skilled and l-workers who are low-skilled. By 'skill' we understand unobservable personal traits as ambitions, effort and in general productivity. Those who are high-skilled never fail in the tasks which they perform during their career, while type- $l$ workers sometimes fail when they are recruited into positions as VPs or CEOs. Employers believe - and we assume they are right in their belief - that the proportion of men who are of the $h$-type is larger than the proportion of females, $\alpha_{f}<\alpha_{m}$, where $\alpha_{j}$ is the proportion of type $h$ in group $j, j=m$, $f$. Within the two skill groups, $h$ - and $l$-workers, there are no gender differences in skills and productivity, and employers are not assumed to have discriminating preferences.

In order to become promoted up and out of the POP group, workers have to send a number of

\footnotetext{
${ }^{1}$ In the empirical model we also allow POPs to jump directly into a CEO position because this behavior is actually observed in our data.
} 
positive signals to their leaders or supervisors who are responsible for their promotion. The signals help the supervisors to reveal whether potential top executives who have not yet been in a position where they undertake top management decisions and tasks are $h$-workers or $l$-workers. I.e. the signals help the supervisors to promote the most productive members in the POP group. The signals may appear when POPs socialize and communicate with their leaders, either at work or in social activities related to the job. Bjerk (2008) assumes that these signals, positive or negative, are more easily understood by supervisors who come from the same group, i.e. men are better in understanding and decoding the signals from men, and women better understand signals from other women. The reason may be gender differences in communication styles and topics or psychological mechanisms. The probability that an $l$-worker via the signals reveals himself as an $l$-worker is denoted $\lambda_{j}$, i.e. $\lambda_{j}$ is the probability of sending a negative signal $j, j=m, f$ for individuals who are $l$-workers. $h$-workers always send positive signals. If we assume that leaders who make promotion decisions are men and that men are better in decoding signals from male POPs compared to female POPs, we have that $\lambda_{m}>\lambda_{f}{ }^{2}$

Men and women are assumed to differ with respect to their ability to send signals, for instance because women in the POP group experience more career interruptions than their male peers during the childbearing and child-rearing period. Another reason may be that female potential top executives socialize less with (male) superiors because they are not members of the same networks, or they are not invited or do not accept invitations to the same extent as their male peers to for instance sport events. If women have less experience and tenure due to family responsibilities or social networks and activities etc., they are assumed to send signals with a lower intensity, $\theta$, i.e. $\theta_{f}<\theta_{m}$. The lower female signalling frequency may of course also reflect that women have less preferences for top positions compared to their male peers, either because of taste differences, less self-confidence on own abilities etc., as indicated by recent experimental studies as for instance Niederle and Vesterlund (2007).

Based on these three main assumptions, we apply the results in Bjerk (2008) which show that there

\footnotetext{
${ }^{2}$ An alternative interpretation of $\lambda$ might be that formal or informal mentoring processes within the firm are mainly taking place within same-sex relations, see Athey et al. (2000).
} 
may exist a unique Bayesian Nash Equilibrium where the hiring standards (measured by the expected number of signals that a member of the POP group shall send until promotion into a VP position) are higher for women than for men. More specifically, the probability that the employer considers an individual as being a type $h$-worker conditional that the individual has sent $n$ positive signals is shown to be

$$
p^{j}(n)=\frac{1}{1+\frac{1-\alpha_{j}}{\alpha_{j}}\left(1-\lambda_{j}\right)^{n}}, \text { where } j=m, f
$$

If $\alpha_{f}<\alpha_{m}$ or $\lambda_{m}>\lambda_{f}$, it is easily seen that for a given number of signals, $n$ :

$$
p^{m}(n)>p^{f}(n)
$$

Thus, for a given number of signals, employers will believe that male members of the POP group have a higher probability of being a type $h$-worker compared to female members, cet. par., either because there are relatively more $h$-workers among male POPs or because the employers more easily decode the signals from male POPs than from female POPs.

In order to become promoted into a VP position, an individual from the POP group has to send a sufficient number of positive signals $\left(n_{j}^{*}\right)$ to convince the employer that he/she is a $h$-worker. If the riskneutral employer maximizes expected profit from promoting a POP individual into a VP position, and given supplementary assumptions concerning the expected loss and gains from recruiting from $h$-workers and $l$-workers into VP positions, see Bjerk (2008), the employer calculates a hiring standard $p_{V P}^{*}$ which is the minimum value of the probability given by (1) of being a type $h$-worker in order to become promoted into a VP position. $p_{V P}^{*}$ is denoted the "hiring standard" for promotion into VP positions and it is not assumed to differ between men and women since there is no discriminatory preferences among employers. The number of signals $(n)$ which an individual from the POP group has to send before becoming promoted is given by the minimum solution to

$$
p^{j}(n) \geq p_{V P}^{*}, \text { where } j=m, f \text {. }
$$


Due to the assumptions concerning employers' beliefs or their ability to decode signals $\left(\alpha_{f}<\alpha_{m}\right.$ or $\lambda_{m}>\lambda_{f}$ ), the number of signals that female POPs will have to send before they are promoted into a VP position will be larger, $n_{f}^{*}>n_{m}^{*}$. Further, if women tend to have a lower signalling intensity, i.e. $\theta_{f}<\theta_{m}$, and since hiring standards are the same for male and female applicants, the model implies that female members of the POP group will on average be older when they are promoted into a VP position. The fewer women employers believe are $h$-workers, the more difficult female signals are decoded, and the more children and long leave periods out of the labor market that female executives have had, the lower is the probability that they are promoted to a VP position, cet. par.

When being employed in a VP position, the individual is assumed to take important management decisions and the employer (now the owner of the company or the board of directors) no longer has to rely on signals. Instead they observe the number of successful tasks undertaken by the VP, $s_{j}, j=f, m$. The probability that an $l$-worker employed as a VP fails in doing a task is $\pi$ ( $h$-workers never fail). In the model by Fryer (2007), the employer uses the information that individuals from the minority group (women) are a more positively selected group than male VPs. Thus, the Fryer model predicts that in the next promotion step women will benefit from this knowledge and will face "belief flipping", i.e. face "inverse statistical discrimination" and have higher promotion probabilities than their male peers. Contrary to Fryer, Bjerk (2008) assumes that employers apply gender-neutral information on actual performance in the job as a VP. Since the employers know that individuals in VP positions have fulfilled the condition for becoming a VP, i.e. $p^{j}(n)>p_{V P}^{*}$, this information is used when the employer, the board of directors, or the owners of the company consider the promotion into a CEO position instead of the less informative information given by $\alpha_{j}$. Information on $s_{j}$ and $p_{V P}^{*}$ is used to calculate whether a VP who applies for a CEO position fulfills the hiring standard for a CEO position, $p_{C E O}^{*} \cdot{ }^{3}$ The employer will believe that an individual in a VP position who has completed $s_{j}, j=f, m$ successful tasks in the VP job is a $h$-worker

\footnotetext{
${ }^{3}$ It can be shown that if the expected cost of employing an $l$-worker who fails is larger for a CEO position than for a VP position, a profit maximizing employer (board of directors) will have higher hiring standards for CEO positions than for VP positions, i.e. $p_{v p}^{*}<p_{C E O}^{*}$, see Bjerk (2008).
} 
with a probability

$$
p\left(s_{j}\right)=\frac{1}{1+\frac{1-p_{V P}^{*}}{p_{V P}^{*}}(1-\pi)^{s_{j}}}
$$

Promotion into a $\mathrm{CEO}$ position requires that this probability exceeds the hiring standard $p_{C E O}^{*}$, i.e.

$$
p\left(s_{j}\right) \geq p_{C E O}^{*}
$$

Since the hiring standards and the probability of being successful in doing the tasks in VP positions $(1-\pi)$ are the same for men and women, and since the performance of the individual worker, i.e. the number of successful tasks, $s_{j}$, is the only parameter which matters, not the group mean, $\alpha_{j}$, this means that there is no statistical discrimination taking place when promoting into CEO positions. There may still be lower observed promotion rates for women from VP to CEO if female VPs do not complete as many successful tasks as their male peers, i.e. have smaller values of $s_{j}$ at a given age or for given observed human capital variables for the same reasons as their lower signalling intensity in the first step from POP to VP. But controlling for $s_{j}$ by for instance controlling for number of years of experience or number of years spent in VP positions, one should expect no gender difference in promotion rates in the Bjerk model, contrary to the Fryer model which predicts a higher female promotion rate.

When focusing on promotion into the top level position as a CEO, the results in the Fryer and Bjerk models may not be fully applicable because the decision on whom to hire for the CEO position in the company may be different from other top executive positions at lower levels in the company. ${ }^{4}$ Often the "decision-making agent" is different for the CEO position where it is the board of directors or the chairman of the board of directors who are responsible and may often take decisions assisted by professional headhunters or consultants (for large firm this may of course also happen for VP positions). The decision process in a given company may function more like a tournament with $m$ contestants where

\footnotetext{
${ }^{4}$ We may consider the probability in (5) as describing the probability of "promotion into a CEO position" in a very broad way, not restricted to internal recruitment within a given company, if the information on having performed succesful tasks is common knowledge among all firms or headhunters who assist in the CEO hiring proces. In this case (5) may still hold. In this study we do not distinguish between internal and external promotions, and do not test whether the gender gap differs depending on external or internal promotion.
} 
only the 'winner' gets the CEO position, i.e. there is no implicit hiring standard as indicated by (5). Instead, the board chooses among the best contestants who have performed best and supplied the highest level of effort (now reflected in $s_{i}$ ). Thus, the probability of becoming promoted for individual $i$ may be formulated $\mathrm{as}^{5}$

$$
P_{i}=P\left[p\left(s_{i}\right)=\max _{j \in m}\left\{p\left(s_{j}\right)\right\}\right]
$$

This may change the implication of the model with respect to a potential gender gap in promotion chances into CEO positions:

(a) The cost for the company if an l-type individual is promoted into the CEO position and fails is typically much larger than for lower positions. If the board of directors are (more) risk-averse when it comes to the CEO decision, they may be more reluctant to employ individuals from the minority group. Another mechanism may be that the board of directors or the chairman of the board may be more external to the company and to a smaller extent rely on actual information on successful tasks $\left(s_{j}\right)$ and to a larger extent rely on gender stereotype attitudes and biased evaluations compared to the promotion process at lower levels where the hiring agent is internal in the company and more directly observes performance.

(b) The concept 'successful task' may not be an objective concept. If male supervisors or headhunters (unconsciously) suffer from old-fashioned beliefs on female productivity, effort, and behavior, there may be statistical discrimination forces taking place at this step in the evaluation of what is a successful task, i.e. $\pi$ in (4) may differ between male and female VPs even when they have the same productivity and skills.

(c) For a given $s_{j}$, female VPs may find it less attractive to apply for CEO positions and be in the contestant pool if they have less preferences for the responsibilities associated with the job as a CEO and are less self-confident with respect to own abilities (underestimate $s_{j}$ and send signals which underreport

\footnotetext{
${ }^{5}$ This way of reformulating the model is a very simple way of introducing the tournament concept. Alternatively, the statistical discrimination model may be combined with a more formal tournament approach in line with Lazear and Rosen (1981) where gender differences in effort of the agents may give rise to gender differences in promotion rates. Fryer and Bjerk do not explicitly model the promotion process between the two highest levels in the company as we do in this paper. Thus (6) should be considered a potential 'supplement' to the more general promotion models in Fryer and Bjerk.
} 
$\left.s_{j}\right)$. This may induce a gender gap with respect to who applies for CEO positions which does not exist (to the same extent) for lower positions.

Thus, we expect that there may also exist a negative gender gap in promotion probabilities into CEO positions, contrary to the Bjerk model which predicts no gap and the Fryer model which predicts a positive gap, i.e. that females have higher promotion probabilities, cet. par.

\subsection{Empirical Model}

The empirical model is a reduced form model where we estimate the gender gap in the probabilities of promotion from POP to VP and from VP to CEO, i.e. the probability of becoming a CEO conditional of being in a VP position. Thus we estimate the probability that the expressions given by (3) and (5) are fulfilled for executive $i$ :

(7) Promotion I (to a $V P$ position): $\quad P_{i}\left(p^{j}(n)>p_{V P}^{*}\right)$

(8) Promotion II (to a $C E O$ position): $P_{i}\left(p\left(s_{j}\right)>p_{C E O}^{*}\right)$ or $P\left[p\left(s_{i}\right)=\max _{j \in m}\left\{p\left(s_{j}\right)\right\}\right]$

(7) and (8) are estimated on the employer-employee data set described in Section 5 which allows us to control for both observed firm-specific factors $\left(x_{j t}\right)$ in the recruiting firms, individual-specific factors $\left(x_{i t}\right)$, and unobserved heterogeneity captured by the time-invariant firm-specific and individual-specific terms, $\mu_{j}$ and $\mu_{i}$. The key variable $F$ is an indicator variable assuming the value of 1 for women, and 0 else. If the latent variable for Promotion $k=V P, C E O$ of individual $i$ in firm $j$ at time $t$ is denoted $y_{i j t}^{k}$, the model is given by

(9) $y_{i j t}^{k}=\delta^{k} F_{i}+x_{i t}^{\prime} \beta^{k}+x_{j t}^{\prime} \gamma^{k}+\mu_{i}^{k}+\mu_{j}^{k}+\nu_{i j t}^{k}$,

where $i=1, \ldots, M, \quad j=1, \ldots, N, \quad t=1, \ldots, T, k=V P, C E O$, and $\nu_{i j t}^{k}$ is a random error term.

The empirical hypotheses to be tested are:

(i) $\delta^{V P}<0$, reflecting $\alpha_{f}<\alpha_{m}$ and/or $\lambda_{m}>\lambda_{f}$, and/or $\theta_{f}<\theta_{m}$. 
(ii) $\delta^{C E O}>0$ if belief flipping (Fryer),

$\delta^{C E O}=0$ if gender-neutral promotion within the career track (Bjerk) or

$\delta^{C E O}<0$ if CEO promotions are described by tournament processes given by (6).

Further, we test how the estimates of $\delta^{V P}$ and $\delta^{C E O}$ are affected by including additional explanatory variables to the model in (9) which are supposed to proxy the gender-specific parameters determining the probabilities in (3), (5) and (6):

(iii.a) The signalling intensity, $\theta_{j}$ and the number of successful tasks completed in VP positions $\left(s_{j}\right)$ are expected to differ between male and female executives. We test whether $\delta^{V P}$ and $\delta^{C E O}$ become insignificant when controlling for (gender specific) effects of tenure and children, age at first childbirth, time spent on parental leave, and the career of the spouse. We expect that the number of children and the time spent in maternity leave have a negative effect on promotion chances of female executives. We also expect that age at first childbirth has a positive effect on the career for women (but not necessarily for men) because having completed an education and having established a career before childbirth may improve the chances that women are able to come back on the career track after childbirth. We also expect that being married to a spouse who is a CEO has a negative effect on the promotion chances on women where the occupation of the spouse is taken as a proxy for division of work within the household.

(iii.b) Firm-specific factors may proxy the parameters, $\lambda_{j}$ and $\alpha_{j}$. We test whether $\delta^{V P}$ and $\delta^{C E O}$ become insignificant when controlling for (gender-specific) effects of a 'female-led' recruiting company (i.e. led by a female CEO or chairman of the board of directors), the (male) CEO having at least one adult daughter aged 25 years or more which may have changed his belief about female effort and ambitions, see for instance Doepke and Tertilt (2009).

The model is estimated by a panel logit estimator. We apply a random effects (RE) specification where we treat either $\mu_{i}^{k}$ or $\mu_{j}^{k}$ as random effects capturing time-invariant heterogeneity among individuals or firms. ${ }^{6}$ It is not possible to model both types of heterogeneity simultaneously. The RE logit model requires

\footnotetext{
${ }^{6}$ The models are estimated by the STATA procedure "xtprobit" which is a conditional MLE procedure using quadrature optimizing (Gauss-Hermite with 12 evaluation points). Since the key variable $F$ is time-invariant, FE estimations which
} 
that $\mu_{i}^{k}$ and $\mu_{j}^{k}$ are independent of the included explanatory variables and are normally distributed, see

for instance Wooldridge (2002). If $\mu_{i}^{k}$ is correlated with $F$, for instance if women in general are more risk-averse than men or have less preferences for power and leadership, this may bias the estimate of $\delta^{V P}$ and $\delta^{C E O}$ downwards (more negative estimate). The assumptions behind the RE model are evaluated in alternative ways. First, a pooled logit estimation is applied. Secondly, RE models which include the time-invariant unobservables terms $\mu_{i}^{k}$ and $\mu_{j}^{k}$, respectively, are estimated. The empirical strategy is to add a large number of control variables from the extremely rich data set available which includes historical information on spouses, childbirths, leave periods etc. and in this way be able to control for most of the relevant heterogeneity for the promotion process.

However, it is obvious that one has to be careful in the interpretation of the parameter estimates which cannot be considered causal effects since more of the variables may be endogenous to the promotion probabilities. For instance, if a potential executive does not succeed in becoming promoted, he or she may choose to have more children cet. par., and the timing decisions with respect to having children may be endogenous to career aspirations, see for instance Miller (2010). Also unobserved variables may affect both the promotion probabilities and some of the right-hand side variables, for instance preferences for career or family values. Part of the endogeneity problems due to unobservables may be captured by the panel estimator $\left(\mu_{i}\right.$ effects) if the unobserved variables are time-invariant. But some of the important unobservables, like career aspirations, may change over the life cycle, see a discussion of the 'fixed-effectscritique' in Lundberg (2005).

In order to test and control for endogeneity of the key variable $F$, firm-specific mean values of $F(\bar{F})$ are added to the model in (9) in the RE (firm-specific) estimation. The same procedure is applied for other individual-specific family-related variables. There it is not possible to use the individual-specific

controls for individual-specific time-invariant unobservables are not feasible. Further, the FE estimator in non-linear probit models is not as attractive as in linear models, see Wooldridge (2002). Therefore, we select the RE approach. In alternative estimations not shown here, we have also experimented with FE probit models which control for firm-specific time-invariant unobservables. The results concerning the coefficient $\delta$ from these alternative estimations do not deviate from the results shown below. 
RE estimations since F (and other individual-specific family variables) are time-invariant for individuals, but not firms).We test whether the coefficient of $\bar{F}$ is significant, see Wooldridge (2002, p. 488). The test values are significant in all specifications.

\section{Data}

The data set is a merged employer-employee panel sample of all Danish companies observed during the period 1996-2007. The companies are privately owned or listed firms. Information from administrative registers is supplemented with information from a private Danish data account register, Experian. We restrict the sample to executives who are either in a CEO or VP position, and executives who are at a hierarchical level just below CEOs and VPs, denoted the pool of potentials, POPs. ${ }^{7}$ The definition of a $\mathrm{CEO}$ and a VP is restricted to individuals who are top executives in medium-sized or larger companies with at least 50 employees. Since there are many small firms in Denmark, and since a relatively large proportion of women start their careers in smaller companies, we also consider a jump from a CEO or VP position in a small company with less than 50 employees into a position as VP or CEO in a medium or large company as a promotion. This means that the top executive in a company with less than 50 employees is included in the POP group. Given our definition, there is only one CEO in a firm, while there may be one or more often a number of VPs. In total, there are 3,053 companies and 57,632 executives in 2007, see Table 1.

(Table 1 about here)

Figure 1 shows the female proportion in the three executive categories for the sample period, 19962007. According to Figure 1, times are changing in the sense that more women have entered top executive

\footnotetext{
${ }^{7}$ The exact definition using the Statistics Denmark's 'DISCO-codes' is: CEO=Executive director (RAS-DISCO code 121, 1210). VP=Vice-President (DISCO 122, 123, 1221-1239). Pool of potentials=Potential executives (CEO or VP). (First digit of DISCO code is 1 but not included in the groups of top or vice directors). The registration of the DISCO codes in the administrative registers has been improved during the observation period. In order to remove outliers or errors in the DISCO codes, we restrict the CEO group to individuals who are observed with an annual earnings in top 10 of the firm. The VP-group is restricted to individuals who are observed among the top 25 .
} 
positions during the period 1996-2007. In 1996, $4 \%$ of the CEOs were women. Ten years later, this figure had almost doubled to $7.5 \%$ ! Also at the lower levels, the female proportion increased.

(Figure 1 about here)

According to Table 1, in 2007, 1890 individuals were promoted into VP positions and 480 were promoted into a CEO position. Figure 2 shows the gender-specific promotion rates 1997-2007. ${ }^{8}$

(Figure 2 about here)

There is a clear cyclical pattern in the promotion rates with more promotions taking place before the cyclical downturn in 2001. In general, all promotion rates in all years are higher for male executives than for female executives. Contrary to the predictions from the Bjerk and Fryer models, the gender gap in the 'raw' promotion rates is lower for promotions from POP to VP (about $1 \%$ ) compared to promotions from VP to CEO positions (about 1.7\%).

The included explanatory variables in the estimations represent individual- $\left(x_{i t}\right)$ as well as firm-specific $\left(x_{j t}\right)$ characteristics:

$x_{i t}$ : Age, age squared, employment experience, experience squared, tenure, and educational level. Employment experience (and tenure) is measured as the accumulated number of years spent in employment (in the company). Periods in part-time employment is counted as half of full-time employment. We are not able to measure over time work or individuals holding more than one job since the employment variables are based on pension payments to a compulsory pension scheme (ATP). In some of the estimations we add information on tenure in different positions, i.e. number of years spent as POP or VP in order to get proxies for the number of signals or successful tasks which the executive has been able to undertake. Education level is measured by a number of indicators for educational level allowing for non-linear effects

\footnotetext{
${ }^{8}$ In the Appendix, Table A1 shows the number of observations who are 'at risk' of becoming promoted, the absolute number of promoted executives, and the promotion rates by gender during the sample period1997-2007. The occupational information (DISCO codes) is based on annual information where we observe the occupational position ultimo November. This means that we are not able to observe more promotions during the year, for instance a promotion first into a VP position and then shortly after further into a CEO position. Depending on when it happens during the year this may be registered as a jump from a position as 'POP' directly into the CEO category. These observations are excluded.
} 
of education. Excluded category is no education beyond compulsory school. Child variables are indicators for number of children $(1,2$, and $3+)$. Excluded category is 'no children'. In some of the estimations we also include information on the spouse or cohabitant of the executive. These variables are an indicator for being married or cohabiting with a spouse who is a CEO and an indicator for being married or cohabiting with a spouse who is not a CEO. Excluded category is 'single'.

In order to test whether the timing of childbirth matters for the career as is found in many other studies, we include in some of the estimations the variable age at first childbirth (age when becoming a parent for the first time), the number of years since last birth of child. (i.e. age of youngest child), and alternative measures on time spent out of the labor market in a parental leave scheme. From the social registers we have information on the number of days spent each year on maternity, paternity and parental leave for all individuals, including information on the spouses that the individuals were living together with at the time of childbirth in the past. Based on this information, we calculate the accumulated number of days spent in child-related leave schemes during the career, and the same for the spouse, (if the individual was not single after childbirth). These variables reflect time spent out of the labor market but may also proxy division of household responsibilities.

$x_{j t}$ : Firm size is measured by the number of employees (represented by 4 categories to allow for nonlinearities: CEO or VP in a company with less than 50 employees, 50-100 employees, 100-500 employees, and more than 500 employees). We include information on firm size both for recruiting firm and origin firm. For all other firm variables, the information concerns recruiting firm: An indicator for being listed on stock exchange, firm profits ROE (Return On Equities), industry indicators (Energy, Building and construction, Hotel and restaurants, Transportations and telecommunications, and Finance), and female proportion of employees. In some of the estimations we include variables reflecting whether the firm is 'women-led': Indicators for being promoted into a firm with a female on the board, a female CEO, or at least one woman among the group of VPs in the firm. All firm variables are lagged one year.

Sample means for the main variables in the basic model are shown in Appendix Table A2. 


\section{Estimation Results}

\subsection{The Gender Gap in Promotion Probabilities}

The estimated marginal effects from the female indicator $(F)$ are reported in Table 2 for different specifications of the random effects (RE) logit models. The upper part of Table 2 refers to promotion from POP to VP positions and the lower part refers to promotion from VP to CEO. In column 1, only the female indicator and time indicators are included while in column 2 the 'basic' individual human capital and firm variables are included. In general, all estimates of the parameter $\delta$ are significantly negative, and controlling for individual human capital and firm variables does not affect the size of the estimated coefficient. Thus, we cannot reject hypothesis (i) that $\delta$ is negative, i.e. there seems to be a gender gap in the hiring probabilities into VP and CEO positions in Danish companies.

The estimated marginal effect of being a woman in the pooled logit estimations is about -0.006 for promotion I and more negative, -0.016 for promotion II. When controlling for individual-specific timeinvariant unobservables, the numerical size is reduced to about -0.003 and -0.009 for promotions I and II, respectively. Controlling for firm-specific effects in promotion from POP to VP does not affect the estimate of $\delta$ compared to controlling for individual-specific effects. But for promotion from VP to CEO, the firm-specific RE estimate of $\delta$ turns more negative, about -0.017 , i.e. almost the same estimate as in the pooled logit. Finally, we show the results from our preferred estimator $(-0.003$ and -0.021 for promotion I and II, respectively) where we control for potential endogeneity of the $F$-variable by including the firm-specific means value of $F$ in the regression. Our estimation strategy is to use the firm-specific RE estimator because it allows us to control for potential endogeneity of included variables, including the gender dummy. Further, in the next sections we add a large number of family and household variables, in order to control as much as possible for individual-specific heterogeneity which may affect our estimate of $\delta .9$

\footnotetext{
${ }^{9}$ One might argue that the individual-specific RE estimator should be preferred. However, this estimator is clearly subject to the 'fixed effect critique' that unobservables for instance related to career preferences and family formation are not constant.
} 
(Table 2 about here)

In 2007, the raw gender gap for POP to VP promotions was 0.01, see Table1. By including observable individual and firm characteristics and time-invariant unobservable firm characteristics, we are able to 'reduce' this gap to 0.03. For promotions into CEO positions, the observed gap was 0.017. In the preferred estimation, controlling for observables and firm-specific time -invariant heterogeneity, the gender gap increased from 0.017 to 0.021 ! Firstly, these results indicate that observable firm and individual characteristics in the basic model do not 'explain' the observed gender gap. We cannot confirm hypothesis (ii) that the estimated effect $(\delta)$ from statistical discrimination is numerically larger at lower levels of the firm hierarchy compared to the gender gap for promotions into CEO positions. This must reflect either that the theoretical model for CEO promotions is more in line with a tournament process, or that 'belief flipping' or a gender neutral promotion process as in the models by Fryer and Bjerk are not dominating. Alternatively, the explanation could be that we do not add enough control variables to capture gender differences in the parameters of these models.

\subsection{Tenure in Different Positions}

As a first step to explain the unexplained 'gender gap' in Table 2, we split the experience variable into variables reflecting the time spent in different positions and allow both experience variables to have gender-specific effects on the promotion probabilities. In Table 3, the conditional sample means of the variables age, experience, and tenure are shown for the year when a promotion occurs. Contrary to a priori expectations, men are on average more than two years older than women when they are promoted into VP positions (for men 41.7 years and 39.4 for women). The same picture holds for CEO promotions (average age at promotion for men is 42.7 years and 41.0 for women). Women also tend to have less total experience when promoted into $\mathrm{VP}$ and $\mathrm{CEO}$ positions though the difference is not significant for the latter group. Finally in columns 3-5, the position-specific experience as POP and VP is shown for those who are promoted into VP and CEO positions. According to the theoretical model, one might expect 
that women had to have longer experience in lower positions before they were promoted because they were not able to signal as intensively, or because their signals were more unclear. However, there are no significant differences between men and women with respect to the average number of years they spend as POP and VP until they are promoted into a higher level, conditional on being promoted. ${ }^{10}$ When we add occupation-specific experience and tenure into the preferred basic model estimated in Table 2 (and allow for gender-specific effects of these variables by interacting with gender), it does not reduce the estimated gender gap in promotion into VP and CEO positions, see Appendix, Table A3.

\section{(Table 3 about here)}

\subsection{Children and Husbands}

As the next step to explain the unexplained 'gender gap' $\delta$, we include the number of children and the position of the spouse as additional explanatory variables. The impact of children may run through a number of channels. The more children in the family, the more income is needed to sustain a given level of living standards. Usually, this income effect of children is stressed as an explanation of the positive impact that children tend to have on fathers' careers. For mothers, the 'child effect' may be split into a number of different factors, assuming that mothers are the main caregivers for children during their childhood. Applying the structure of the theoretical model, children are mainly assumed to affect the signalling intensity of the mothers, $\theta$, and the number of successful tasks that mothers can perform during their early career, $s$. There may also be an effect on the effort that women supply in the job, i.e. in practice the states as being $h$ - or $l$-workers may change over the life cycle: having children may change the status from being an $h$-worker to being an $l$-worker. Further, the occupation of the spouse (whether spouse is a CEO or has a lower position than a CEO position, excluded category is 'single') is assumed to proxy distribution of housework within the family. We expect that being married to a spouse who is a CEO will

\footnotetext{
${ }^{10}$ Part of the reason that women are promoted at a relatively young age may be compositional effects due to the fact that there are very few older women among the group of executives while the proportion of women is growing among the younger cohorts.
} 
reduce effort and chances of becoming promoted.

Table 4 shows the sample values of these variables in 2007. In general, women in VP and CEO positions have fewer children compared to their male peers. But the differences are not as significant as found in many other countries. $13 \%$ of the female CEOs have 3 kids or more (same figure for men is 30 \%). We also find that more female CEOs are singles, i.e. unmarried or divorced (24\% compared to $8 \%$ of the male CEOs). $15 \%$ of the female CEOs are married to a CEO while the same figure for male CEOs is only $5 \%$.

\section{(Tables 4 and 5 about here)}

Do these gender differences in sample means of proxy variables for household responsibilities explain the gender gap in promotion probabilities? In Table 5, the estimates of $\delta$ are shown after adding child and spouse variables and gender interaction terms to the model. The answer is 'no'. The estimate of $\delta$ is reduced, especially for VP-promotions, but still significant.

It is interesting to look at the sign and size of the coefficients of the child and spouse variables, despite one should be careful with causal interpretations of these variables (though as discussed in Section 2 we include firm means of these variables as instruments in the regression). The main effects of the spouse and child indicators are all significantly positive while the interaction terms are negative and significant in most cases. Thus, according to a priori expectations married men who are fathers tend to have higher promotion rates into VP and CEO positions than single men and childless men. For women, this pattern is not observed. For male executives, the size of the coefficients seems to indicate that the more children the better! For women who have not reached VP or CEO positions, the overall effect of children is that the more children, the lower probability of promotion into a VP position. Surprisingly, the numerical size of the negative child effect on female CEO promotion rates is not increasing with number of children. The indicator for having 3 or more children even becomes insignificant for female promotions into CEO positions. Being married, even to a male CEO, does not reduce the promotion probability into CEO positions for women. However, for women at lower ladders of their career, being married reduces the 
promotion chances into CEO positions.

\subsection{Timing of Childbirths and Maternity Leave}

In order to dig further down in the influence of children, we use the sample information on the timing of childbirths and maternity and paternity leave periods spent out of the labor force in the past. Since the late 1970s, Danish mothers have had the right to maternity leave with partly or full compensation, and the duration of the maternity leave period has been extended gradually. In the first part of the observed period, up to 2002 , women were entitled to 14 weeks of maternity leave, fathers had two weeks and there was a parental leave period of 10 weeks which either of the parents could take up, see Gupta et al. (2008). Furthermore, there was a childcare leave scheme available for most parents. In 2002, the schemes were changed and the childcare leave was 'converted' into a formal parental leave of 26 weeks on top of the 10

weeks. Thus, since 2002 the maternity and parental leave period added up to 12 months per child. In total about $6 \%$ of the days spent in maternity and parental leave is picked up by fathers (population figures for Denmark), and this proportion has been quite stable since 1990. Virtually all families, including high income families in top executive positions, take-up the full leave period, see Gupta et al. (2008) for a more detailed description of the Danish leave schemes.

This picture is confirmed by the sample means in Table 6 . In the full sample, i.e. including executives with no children, the proportion who has ever taken maternity leave for more than 2 weeks is almost the same across occupational positions, 18-27\% for males and 59-65\% for females. However, when conditioning on being parents, some differences appear across the three groups of executives. The higher up in the hierarchy, the fewer days spent in paternity leave for male executives. But for females this pattern is not observed which may partly reflect that female CEOs on average are older and for this reason tend to have more kids, cet. par., see Table 4. On average, female (male) POPs have taken-up 396 (17) days of maternal/parental leave during their career. For VPs, these sample means are 347 and 14 
days, for females and males respectively, and for CEOs 355 and 11 days. ${ }^{11}$ According to Table 6, women are on average about one year younger (27 years) than men (28 years) when they become parents for the first time with no notable difference between POPs, VPs and CEOs. On average, the youngest child is aged between 15-17 years for the three groups. Fertility and career may of course interact in a complex way which we do not aim to model in this paper, see Miller (2010).

(Tables 6 and 7 about here)

Table 7 shows the results from reestimating the model in Table 5 with additional variables reflecting alternative measures of take-up of leave periods due to childbirth. The leave period variables are added to the model in Table 5, one at a time, i.e. five alternative models are estimated for each promotion rate. The results reveal that there is still a significant estimate of $\delta$ in all models. Thus, in general we are not able to confirm hypothesis iii.a, i.e. that the estimated gender gap in promotion probabilities is reduced when including variables reflecting timing and duration of leave periods.

In most cases, there are significant gender differences with respect to the coefficient of leave variables (models $i-i i i)$. In general, the estimate of the parameter of take-up of leave schemes (main effect) is significantly negative, as found in many other studies, see for instance Bertrand et al. (2010). But the marginal female interaction effect tends to be positive and of about the same numerical size as the negative main effect. Thus, men who take-up parental leave schemes tend to have lower promotion chances, but for women there is no observed relation between take-up of parental leave schemes and promotion chances. These results fit into the general statistical discrimination explanation and signalling theory: If all women, including potential top executives, are expected to take-up most of the leave periods which they are eligible to, the individual woman is not "punished" when actually taking-up her maternal/parental leave, while the very few fathers who take-up part of the parental leave period (i.e. more than 2 weeks which is about

\footnotetext{
${ }^{11}$ Since data do not include information on maternity leave before 1984, we restrict the sample to women who had their first child after 1984. In the estimations we include all individuals, but include a dummy variable assuming the value of 1 for those individuals who were observed to give birth to their first child before 1984. Spouse information on leave periods is only available after 1992. Thus, the variable 'proportion of leave days' is only defined for individuals having their first child after 1992. Again, we include all observations, but add a dummy variable assuming the value of 1 for indviduals who had children before 1992 .
} 
the average take-up for Danish fathers) send a very negative signal to the employer, see Albrecht et al. (1999). However, when interpreting the results in the framework put up in the theoretical model, the results are less clear. From the predictions of Bjerk's model, it would be expected that the effects were numerically larger for promotions into VP positions where the negative signalling effect of ever having taken-up parental or maternity leave might be more serious for promotions into VP positions than for promotions from VP to CEO positions. And analogously for the other two leave variables. But the estimated marginal effects are numerically largest (though often not significant) for promotions into CEO positions.

The estimated marginal effect of age at first childbirth is significantly positive for promotion from POP to VP, i.e. the probability of being promoted into a VP position increases with age when being parent for the first time. However, for CEO positions, the picture seems to be different. The main effect of 'age at first childbirth' is insignificant, but the estimated interaction effect is numerically large and significantly negative. ${ }^{12}$ Thus, the estimations in Table 7 do not indicate that a good career advice for women is to wait to have children until the career is fixed! Age at first birth seems to 'catch' an important aspect in the promotion process. One hypothesis may be that women who have their first child very early in their career and succeed in reaching a position in the group of VPs, have more success in their signalling as POPs or in doing successful tasks as VPs. There may be more reasons: Either they become more effective during their career when they have children early, or the fact that they have children early and still pursue a career is taken as a positive indication of being an $h$-worker.

\footnotetext{
${ }^{12}$ The variables 'age at first childbirth' and 'years since last childbirth' assume the value of 0 for childless individuals and we include a dummy for childless indviduals in order to secure that these observations do not affect the estimate of the two variables. 'Age at first childbirth' is a time-constant variable, i.e. by defition it does not vary over time for an individual. Therefore, the dummy for childless individuals is not identical with the dummy for having no children in a given year, i.e. we are able to identify the child indicators. We have experimented with many different specifications in order to test the robustness of the numerically large coefficient of the interaction term in model $i v$, but the result seems to be extremely stable. One hypothesis might be that the variable 'age at first childbirth' catches differences in female birth cohorts where old cohorts tended to have their children earlier. However, this is not the case. Firstly, we control for age in the model. Secondly, more detailed descriptions of the variable 'age at first childbirth' do not reveal any systematic differences between age groups or between the three groups of POPs, VPs and CEOs, see Table A4.
} 


\subsection{Female-Friendly or Female-Led Firms and Promotion}

In the search for observed variables which may explain the estimated 'unexplained gender gap', $\hat{\delta}$, we now look to variables on the company-side which may explain the promotion gap. If the firm has a female CEO, this may affect the promotion chances of females into VP positions in the firm, either because these more or less female-led firms may have different information on female applicants or less prejudices against women, or they may be better in decoding the signals from female applicants (i.e. $\lambda_{f}$ is larger in female-led firms). In Models $i$-ii, we test these hypotheses. Another potential effect may be that a male CEO may be influenced by his own family in his perception of women, either his wife or daughters may affect the 'belief' of a male CEO with respect to female skills and productivity. ${ }^{13}$ We test a hypothesis that a male $\mathrm{CEO}$ who is either married to a female $\mathrm{CEO} / \mathrm{VP}$ or has at least one adult daughter may have changed his view of (modern) female potential executives more than males who do not have adult daughters or are married to women who do not have their own career. If this is the case, it should be easier for women to become promoted in firms with a male CEO with an adult daughter or a CEO/VP spouse, compared to other firms. In Model iii, we test whether the promotion chances are related to the proportion of women in the management board, i.e. other female VPs. If there are one or more females in the management board, this may affect both the decoding chances of signals of potential top executives $\left(\lambda_{f}\right)$ and the evaluation of tasks performed by women $(\pi)$ contrary to the assumption in Bjerk (2008). We also test for the potential effect of having a large group of female potential top executives which may affect the 'belief' of the size of the $\alpha_{f}$, the proportion of females who are $h$-workers (Model $i v)$. We expect that a higher proportion of females in the POP group of the hiring firm will increase the chances for women to become promoted from POP to VP (but not from VP to CEO). For simplicity we denote this type of effects as 'female-friendly' effects. In Model $v$, we test whether there is a relation between the gender of the chairman of board of directors and the gender of those who are promoted

\footnotetext{
${ }^{13}$ For CEO-promotion, the interpretation of the results Models $i$-ii is complex because there is only one CEO in the company. If a CEO promotion, is observed this means that the previous CEO has left the position. Thus, the coefficient of gender of the previous CEO partly reflects gender differences in CEO turnover. The estimations (not shown here) actually indicate that female CEOs have a higher turnover than male CEOs.
} 
into CEO positions. In Models vi and vii, we include proxies for 'hierarchical distance' between VP and CEO positions. In Model vi, we add the variable 'Annual CEO compensation minus average annual VP compensation', and in Model vii, we add the variable 'Number of VPs in company'. Our expectation is that including these two variables in Models vi - vii may reduce the estimated gender gap in promotion rates into CEO positions if women tend to have larger difficulties in reaching the top position when the 'hierarchical distance' between CEO and VP positions is large, i.e. reflecting that the competition for the CEO position is larger (a more tough tournament). We include estimates for these models also for VP promotions though we do not expect these variables to affect VP promotions. Table A5 shows the sample means for the variables proxying the 'female-led and female-friendly' hypotheses.

\section{(Table 8 about here)}

The size and significance of the estimates of $\delta$ in Table 8 indicate that including alternative variables reflecting 'female-led' or 'female-friendly male leader' variables has an effect on the estimates of $\delta$ in some of the models on VP promotions, but not the models on CEO promotions. Thus, we are partly able to confirm hypothesis (iii.b) that part of the gender gap in promotion chances for POPs into VP positions is explained by variables proxying 'female-friendly' preferences in the hiring companies. However, we are still left with a significant unexplained gender gap in promotion probabilities into CEO positions. In general, we find insignificant estimates (not shown in Table 8) of the marginal effect from the interaction term between having a female chairman of the board of directors or a female CEO of the firm and being a female applicant to a VP position.

\subsection{What Explains Promotions into VP and CEO Positions? A Full Model}

In Table 9, we show the results from a 'full model' where we include most of the family and firm variables entered one at a time in the estimations above in order to test simultaneously the impact of the individualand firm-related factors on promotion rates. A few variables are not included, either because their impact in the previous estimations were minor or because they are by definition correlated with other included 
variables.

(Table 9 about here)

According to Table 9, the unexplained gender gap is insignificant for VP positions, but still about 1 \% points for CEO positions when all explanatory variables are added to the model simultaneously. Most of the family related-variables tend to be much more significant for explaining VP promotions compared to CEO promotions. Most notable is the difference with respect to child coefficients where the results indicate that potential male top executives (POPs) benefit in their career prospects by having children, but for female POPs there is not this positive effect (adding main effect and interaction effect the total effect of children is slightly negative, though not significant in all cases). The significant effect of children disappears for CEO promotions. Compared to the results in Table 5, the variable which according to alternative estimations (not shown here) seems to affect the size of the child coefficients in the CEOrelation is 'age at first childbirth'. When controlling for age at first childbirth, the number of children in itself does not have any significant effect on promotion chances into CEO positions, compared to having no children. The size and sign of the coefficient for the variable age at first childbirth indicate that if the children are born early, conditional of having reached a VP position, children do not harm the career! Our interpretation is that having children early in life, maybe already while being a student, may signal that the woman is a highly productive individual ( $h$-worker). For men, having children early does not give any signal for the supervisors according to Table 9 !

Partly the same picture is found with respect to the career of the spouse. For males, being married improves the chances of promotion while for women this effect is much smaller, but still positive and significant. For CEO promotions, we do not observe any differences between male and females with respect to being married or not. Thus, women who reach a VP position do not seem to suffer with respect to promotion chances from being married, even to a spouse who is also a CEO. As found in Table 7, we find a highly significant and negative effect of taking up paternity leave for the promotion chances of male executives, but not for women. 
The variables related to 'women-led' or female-friendly companies are shown in the lower part of Table 9. The higher the proportion of women on the executive board (VPs and CEOs), the higher the promotion chances. The interpretation is that female VPs and CEOs have a higher turnover! We do not find that a higher proportion of women in the management board increases the chances for female applicants. On the contrary for CEO-positions. This result is different from what is found in Bell (2005) for US firms. Surprisingly, we find a negative effect on female promotion chances for CEO positions from having a female chairman of the board of directors. This may reflect 'queen bee' effects or that female chairmen are at least as gender-stereotype as their male peers, a surprising result which is also found in another recent Danish study by Neergaard et al. (2008). Alternatively, the result may reflect a tokenism-effect, i.e. if there is already one woman on board, no more women are hired.

The estimation of a full model in Table 9 shows that there still is an unexplained gender gap in promotion probabilities for CEO positions when adding a large number of explanatory variables to the model. For VP positions, the unexplained gender gap disappears in Table 9. Thus, as in other studies of the Scandinavian labor market, see Albrecht et al. (2003) and Gupta et al. (2006), our results point to an 'unexplained' gap in the upper end of the labor market which we are not able to attach to individualor firm-specific factors. Instead, we interpret our results as reflecting general mechanisms in the labor market which give rise to statistical discrimination effects. Part of these 'mechanisms' may be that there still exist fairly stereotype views on males and females with respect to management requirements and competencies.

These results may at first glance seem paradoxical for a Scandinavian country like Denmark which was one of the first countries in the Western world where women entered the labor market. However, as analyzed in other papers, see Gupta et al. (2008), it may be part of the 'boomerang effects' of the Scandinavian welfare state model which has facilitated women's entrance into the labor market combined with a high fertility rate, but at the same time it has made it more difficult for women to take the last steps to the top. Scandinavian women, including women at the upper end of the skill distribution, still 
have the main responsibilities at home and take up the majority of the very long maternity and parental leave periods. An alternative explanation may be that women do not find it very attractive to become CEOs because they have to give up too much to fill a CEO position compared to the alternative as being a VP or having a lower position which is more easily combined with having more kids and full take-up of maternity leave schemes and other family-friendly schemes.

\section{Conclusion and Discussion}

This paper analyzes the gender gap in promotion into top corporate jobs based on employer-employee data on all Danish companies. The 'raw' VP- and CEO-promotion rates in the data set show a fairly constant distance between males and females during the period 1997-2007. In 2007, $4.6 \%$ of the males and $3.6 \%$ of the females in the group of potential top executives were promoted into a VP position while for promotions from VP positions into CEO positions, the same figures were $4.4 \%$ and $2.7 \%$, respectively, i.e. there was a gender gap of $1 \%$ points for VP positions and $1.7 \%$ points for CEO positions..

Firstly, we test whether these gender gaps are explained by gender differences in observed characteristics or unobserved time-invariant characteristics of firms or individuals. They are not! I.e. we cannot explain the gender gap by women's lack of formal observed or unobserved time-invariant competencies or, probably more surprisingly, by some firms being constantly more reluctant to hire or promote women into top executive positions. Especially the last step from a VP position to a CEO position seems to be a difficult hurdle for women, also when controlling for a number of background characteristics of the executives and companies. These results are not in line with models proposed by Fryer (2007) and Bjerk (2008).

Secondly, we dig deeper in the explanations behind the gender gap in promotion probabilities by focussing on a number of factors which may have different effects on male and female careers at the top level. We analyze the gender-specific role of children, childbirth, and household responsibilities. We have historical information on maternity, paternity and parental leave periods for the individuals 
(and their spouses) included in the sample. Our results indicate that time out of the labor market and child-related decisions are important factors when explaining the gender gap in promotion into top executive positions. Children seem to benefit the promotion rates of fathers, but have no effect on mothers' promotion chances, cet. par. However, if the fathers take up parental leave, they are strongly punished on career prospects and promotions while the individual woman is not. For the small group of women who succeed in becoming promoted from a VP position into a CEO position, age at first childbirth is strongly negatively correlated with promotion chances, i.e. women who give birth at a relatively young age seem to have higher promotion chances. For this group, the number of children has no significant effect on women's CEO-promotion probabilities. Our interpretation is that women who have their children at a relatively young age (not teenagers, but at the age of around 21-24) and succeed in climbing the career ladder into a position as VP, are able to signal that they are $h$-workers in a more convincing way than women who have their children later in life. Though most of these observed family-related variables are clearly important, we are still not able to explain the gender gap in promotion chances when including these detailed variables reflecting past decisions on leave periods and childbirths even when we allow the coefficients of these variables to be gender-specific.

Therefore, we search for explanations on firms' side. We test a number of hypotheses about the recruiting firm. One hypothesis is that the barriers for women are minor in female-led companies, i.e. companies with a female CEO, a chairman of the board of managers or a female VP. We conclude that female-led firms are either not different from other firms or in some cases hire fewer women into top positions, compared to other companies, contrary to results found for US firms by Bell (2005). The fact that we do not find positive effects for Danish female-led firms fits with other empirical evidence for Denmark saying that female managers may have more gender-stereotype 'beliefs' than male managers on female competences and the requirements for management positions.

This leaves the question: What else explains the low proportion of women in top executive positions and the gender gap in the promotion into these positions? Our hypothesis is that statistical discrimination 
factors due to overall institutional mechanisms in the Danish society (and other Scandinavian countries) are important. These 'welfare state effects' may affect preferences and norms concerning female career choices both on the demand and supply sides in a very general way, common to all individuals and companies. Many women may not find it very attractive to become CEOs because they have to give up too much to fill a CEO position compared to the alternative as being a VP or having a lower position which is more easily combined with having more kids and full take-up of maternity leave schemes and other family-friendly schemes, i.e. to rewrite the words by the former Danish CEO, Stine Bosse: 'Be in positions where they can still have a life'. If this view or expectation is widespread, also among the recruiting board of directors who make the promotion decisions for CEO positions, this may explain at least part of the unexplained gender gap in CEO promotions in Denmark.

\section{References}

Albrecht, J.W., P.-A. Edin, M. Sundstrøm and S.B. Wroman (1999), Career Interruptions and subsequent earnings, Journal of Human Resources. 34, 294-311.

Albrecht, J., A. Bjorklund and S. Vroman (2003), Is There a Glass-Ceiling in Sweden?. Journal of Labor Economics. 21:1,145-77.

Athey, S., C. Avery and P. Zemsky (2000), Mentoring and Diversity, American Economic Review, vol. $90(4), 765-786$.

Bell, L. (2005), Women-Led Firms and the Gender Wage Gap in Top Executive Jobs, IZA Discussion Paper no. 1689

Bertrand, M. and K. Hallock (2001), Industrial and Labor Relations Review, vol. 55, 3-21.

Bertrand, M., C. Goldin and L.F. Katz (2010), Dynamics of the Gender Gap for Young Professionals in the Corporate and Financial Sectors, American Economic Journal : Applied Economics, 2(3), $228-55$.

Bjerk, D. (2008), Glass ceiling or Sticky floors? Statistical Discrimination in a Dynamic Model of Hiring and Promotion, The Economic Journal, 118, 961-982. 
Blau, F. D. and J. DeVaro (2006), New evidence on gender differences in promotion rates: An empirical analysis of a sample of new hires, NBER working paper \#12321.

Booth, A., M. Francesconi and J. Frank (2003), A sticky floors model of promotion, pay, and gender, European Economic Review, vol 47, 295-322.

Booth, A. and P. Nolen (2009), Gender Differences in Risk Behaviour: Does Nurture Matter?, CEPR Discussion Paper 7198.

Cobb-Clark, D. (2001), Getting Ahead: The Determinants of and Payoffs to Internal Promotion for Young US Men and Women, Centre for Economic Policy Research, Australian National University, Discussion Paper no. 430.

Doepke, M. and M. Tertilt (2009), Women's Liberation: What's in It for Men?, Quarterly Journal of Economics 2009 124:4, 1541-1591.

Fietze, S., E. Holst and V. Tobsch (2009), Personality and Career - She's got what it takes, DIW Discussion Paper, No. 955, Berlin.

Frederiksen, A. and T. Kato (2011), Human Capital and Career Success: Evidence from Linked Employer-Employee Data, IZA Discussion Paper no. 5764.

Fryer, R. (2007), Belief flipping in a dynamic model of statistical discrimination, Journal of Public Economics, vol. 91(5\&6), 1151-66.

Gupta, D. N., R. Oaxaca and N. Smith (2006), Swimming Upstream, Floating Downstream: Comparing Women's Relative Wage Progress in the United States and Denmark, Industrial and Labor Relations, 59 (2), 243-66

Gupta, N., N. Smith and M. Verner (2008), The impact of Nordic Countries' family-friendly policies on employment, wages, and children, Review of Economics of the Household, 6:65-89.

Lazear, E. and S. Rosen (1981), Rank-Order Tournaments as Optimum Labor Contracts, Journal of Political Economy 89(5), 106-123

Lazear, E. and S. Rosen (1990), Male-female wage differentials in job ladders, Journal of Labor 
Economics, vol 8, S106-S123.

Lundberg, S. (2005), Men and islands: Dealing with the family in empirical labor economics," Labour Economics, Elsevier, vol. 12(4), 591-612

Matsa, D. A. and A. R. Miller (2011), Chipping away at the Glass Ceiling: Gender Spillovers in Corporate Leadership, http://ssrn.com/abstract=1709462.

McCue, K. (1996), Promotion and Wage Growth, Journal of Labor Economics, vol 14, 175-209

Miller, A. R. (2010), The Effects of Motherhood Timing on Career Path, Journal of Population Economics.

Neergaard, H., M. Hersby, H. Madsen, J. P. Ulhøi and M. T. Madsen (2008), Revisiting the Think Manager-Think Male Syndrome in an Egalitarian Culture, Proceeding, Academy of Management Conference, Anaheim, USA.

Niederle, M. and L. Vesterlund (2007), Do Women Shy away from Competition? Do Men Compete too Much?, Quarterly Journal of Economics, Vol. 122, No. 3, 1067-1101.

OECD. 2002, 2003, 2004, 2005. Babies and Bosses, Reconciling work and family life, Paris.

Phelps, E. S. (1972), The Statistical Theory of Racism and Sexism, American Economc Review, vol 62, 659-61.

Schein, V. E. (1973), The relationship between sex role stereotypes and requisite management characteristics. Journal of Applied Psychology, 57: 95 - 100.

Smith, N., V. Smith and M. Verner (2011), The Gender Pay Gap in Top Corporate Jobs in Denmark - Glass Ceilings, Sticky Floors or Both? International Journal of Manpower, vol 32(2), 156-177.

Wooldridge, J. M. (2002), Econometric Analysis of Cross Section and Panel Data, MIT Press.

World Economic Forum (2010), The Global Gender Gap Report, Geneva. 
Figure 1. Female Share of POPs, VPs and CEOs.

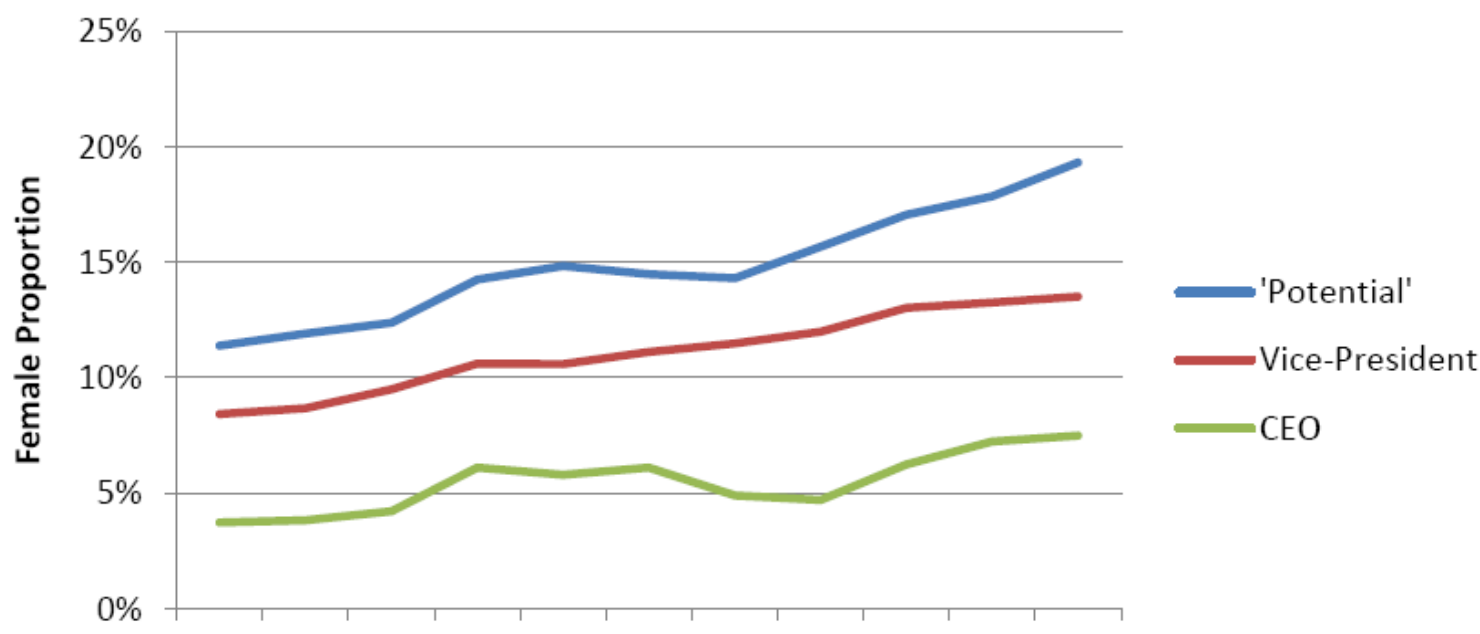

19971998199920002001200220032004200520062007

Figure 2.Promotion Rates into VP and CEO Positions.

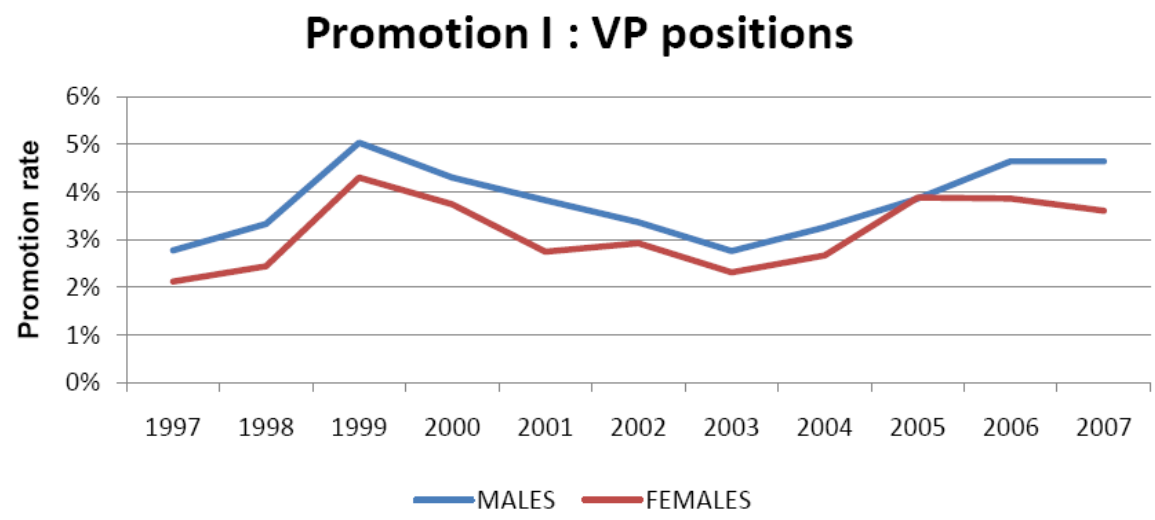

\section{Promotion II: CEO positions}

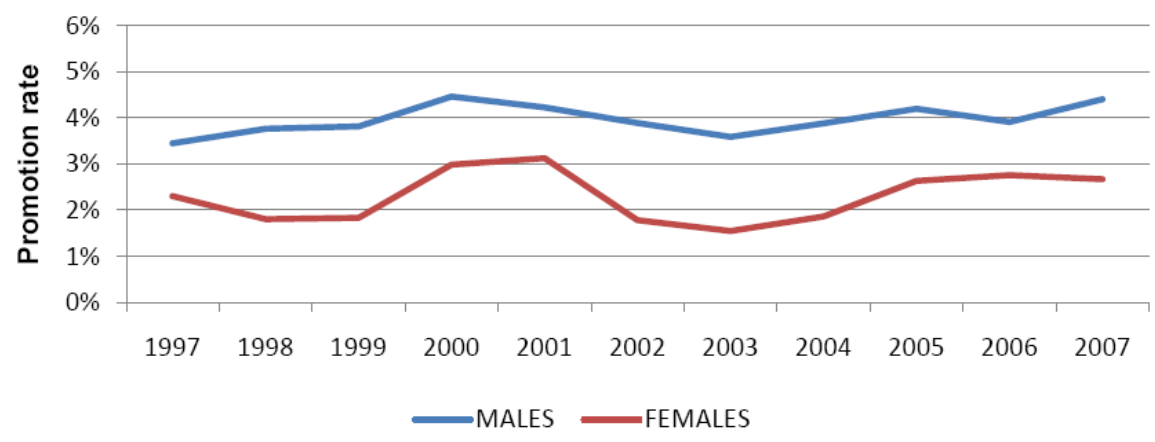


Table 1. Number of Individuals and Promotion Rates. By Gender and Occupational Position. 2007.

\begin{tabular}{lrrr}
\hline & POP & VP & CEO \\
\hline No. of observations in 2007 & & & \\
$\quad$ Males & 34,765 & 9,934 & 2,824 \\
Females & 8,328 & 1,552 & 229 \\
Males and Females & 43,093 & 11,486 & 3,053 \\
& & & \\
Female proportion among POPs, VPs, and CEOs & 0,193 & 0,135 & 0,075 \\
& & & \\
Promotions between 2006-2007 into VP and CEO (in & & & \\
parentheses promotions rates) & $1,618(0.046)$ & $419(0.044)$ \\
$\quad$ Males & $272(0.036)$ & $39(0.027)$ \\
Females & $1,890(0.044)$ & $458(0.040)$ \\
Males and Females & &
\end{tabular}

Table 2.Estimated Marginal Effect on Promotion

Probability of being 'Female'. 'Alternative estimators.

\begin{tabular}{|c|c|c|}
\hline & $\begin{array}{l}\text { Only Time } \\
\text { Indicators }\end{array}$ & $\begin{array}{c}\text { Basic model: } \\
\text { Time } \\
\text { Indicators+HC and } \\
\text { Firm Var }\end{array}$ \\
\hline \multicolumn{3}{|c|}{$\begin{array}{l}\text { Promotion I, VP positions: } \\
\text { Raw Gap 2007: } 0.036-0.046=-0,010\end{array}$} \\
\hline $\begin{array}{l}\text { Pooled logit } \\
\text { Individ. Spec. RE } \\
\text { Firm Spec.RE } \\
\text { Firm specific RE + IV }\end{array}$ & $\begin{array}{l}-0.006 \\
-0.004 \\
-0.003 \\
-0.003\end{array}$ & $\begin{array}{l}-0.008 \\
-0.003 \\
-0.003 \\
-0.003\end{array}$ \\
\hline \multicolumn{3}{|c|}{$\begin{array}{c}\text { Promotion II, CEO positions: } \\
\text { Raw Gap 2007: } 0.027-0.044=-0,017\end{array}$} \\
\hline $\begin{array}{l}\text { Pooled logit } \\
\text { Individ. Spec. RE } \\
\text { Firm Spec.RE } \\
\text { Firm specific RE + IV }\end{array}$ & $\begin{array}{l}-0.016 \\
-0.010 \\
-0.018 \\
-0.018 \\
\end{array}$ & $\begin{array}{l}-0.016 \\
-0.009 \\
-0.017 \\
-0.021 \\
\end{array}$ \\
\hline
\end{tabular}

Note 1: All marginal effects are significant at $0.1 \%$ level. HC variables are experience, experience squared, tenure, age, age squared, and education. Firm variables are firm size, listed on stock exchange, lagged performance, and female share of employees, see Table A2. These firm variables refer to recruiting firm, lagged one year. Further, dummies for size of origin firm (lagged one year) are included. Number of observations in estimation are 499,470 (promotion I) and 116,473(promotion II). 
Table 3. Sample means 1997-2007: Years of experience in different positions and tenure (in company) when promoted, conditional on promotion

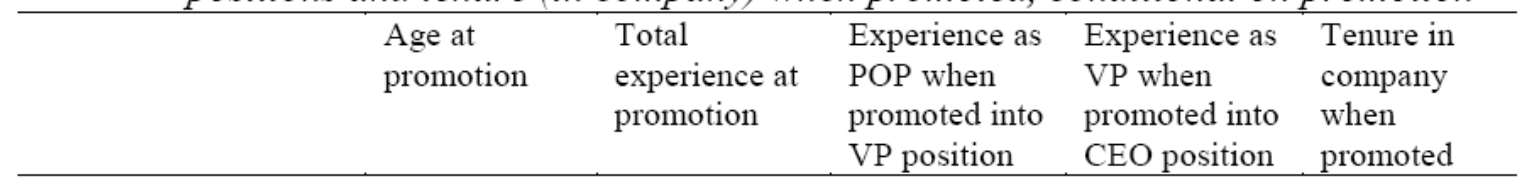

\begin{tabular}{llllll}
\hline $\begin{array}{l}\text { POP to VP } \\
\text { (if same year) }\end{array}$ & & & & & \\
Males & 41.7 & 18.5 & 2.3 & - & 4.0 \\
Females & 39.4 & 16.2 & 2.2 & - & 4.1 \\
VP to CEO & & & & & \\
Males & 42.7 & 18.9 & - & 2.5 & 4.7 \\
Females & 41.0 & 17.8 & - & 2.3 & 4.5 \\
\hline
\end{tabular}

Satterthwaites test for equality between males and females shows that all variable means are significantly different for men and women, except for values in italics. Individuals who already possess a position as POP, VP or CEO when entering the data set are excluded from this table.

Table 4. Sample Means for Child Variables and Spouse Occupation. 2007. By Gender and Occupation.

\begin{tabular}{lcccccc}
\hline & \multicolumn{2}{c}{ POP } & \multicolumn{2}{c}{ VP } & \multicolumn{2}{c}{ CEO } \\
& Males & Females & Males & Females & Males & Females \\
\hline 0 children & 0.32 & 0.31 & 0.11 & 0.25 & 0.08 & 0.25 \\
1 child & 0.14 & 0.18 & 0.15 & 0.19 & 0.13 & 0.16 \\
2 children & 0.36 & 0.39 & 0.50 & 0.45 & 0.49 & 0.46 \\
3+ children & 0.18 & 0.12 & 0.24 & 0.11 & 0.30 & 0.13 \\
& & & & & & \\
Spouse CEO or VP & 0.03 & 0.11 & 0.03 & 0.12 & 0.05 & 0.15 \\
Single & 0.26 & 0.26 & 0.11 & 0.25 & 0.08 & 0.24 \\
& & & & & & 2,824 \\
Number of obs. & 34,765 & 8,328 & 9,934 & 1,552 & 229 \\
\hline
\end{tabular}

Satterthwaites test for equality between males and females shows that all variable means are significantly different for men and women, except for values in italics. 
Table 5. Marginal Effects on Promotion Probability. Child variables and Spouse Occupation interacted by Gender. Firm-Specific RE-IV Estimator. 1997-2007.

\begin{tabular}{|c|c|c|c|c|}
\hline & \multicolumn{2}{|c|}{ Promotion I (VP) } & \multicolumn{2}{|c|}{ Promotion II (CEO) } \\
\hline & Main effect & $\begin{array}{c}\text { Interaction } \\
\text { effect Woman }\end{array}$ & Main effect & $\begin{array}{c}\text { Interaction } \\
\text { effect Woman }\end{array}$ \\
\hline Woman dummy $(0 / 1)$ & $-0.0010^{*}$ & - & $-0.0194^{\text {水水 }}$ & - \\
\hline 1 child $(0 / 1)$ & $0.0020^{*}$ 水水 & $-0.0023^{* k} k_{k}$ & $0.0040^{*}$ & $-0.0130 * k * 2$ \\
\hline 2 children $(0 / 1)$ & $0.0025^{\text {水水 }}$ & $-0.0024^{* k * k}$ & $0.0044^{*}$ * & $-0.0096^{* * k}$ \\
\hline $3+$ children $(0 / 1)$ & 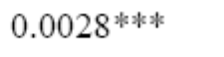 & $-0.0032 * \cdots \cdots$ & $0.0046^{* * *}$ & -0.0088 \\
\hline Spouse_CEO $(0 / 1)$ & $0.0028^{* * * *}$ & 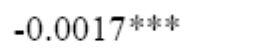 & $0.0127^{* *}$ & -0.0015 \\
\hline Spouse_not_CEO $(0 / 1)$ & $0.0022^{* * * * ⿰ ㇇ ⿰ 亅 ⿱ 丿 丶 丶 ~}$ & $-0.0018^{\text {*ak } k_{k}}$ & $0.0048^{* * * *}$ & -0.0056 \\
\hline $\begin{array}{l}\text { Other explanatory } \\
\text { variables }{ }^{1)}\end{array}$ & Yes & & Yes & \\
\hline Number of observations & 432,685 & & 113,302 & \\
\hline
\end{tabular}

*) significant at $10 \%$, ** significant at $5 \%, * *$ significant at $1 \%$.

Note 1. Explanatory variables are $\mathrm{HC}$ variables occupation-specific experience, experience squared, tenure, age, age squared, and education. Firm variables are firm size, listed on stock exchange, lagged performance, and female share of employees. These firm variables refer to recruiting firm, lagged one year. Further, dummies for size of origin firm (lagged one year) are included.

Table 6. Sample Means of Leave Period Variables by Gender. 1997-2007.

\begin{tabular}{|c|c|c|c|c|c|c|}
\hline & \multicolumn{2}{|c|}{ POP } & \multicolumn{2}{|c|}{ VP } & \multicolumn{2}{|c|}{ CEO } \\
\hline & Male & Female & Male & Female & Male & Female \\
\hline \multirow[t]{2}{*}{ Ever on maternity or parental leave $(0 / 1)$} & 0.195 & 0.588 & 0.267 & 0.654 & 0.182 & 0.630 \\
\hline & \multicolumn{6}{|c|}{ Sample means conditional of giving birth to a child/being a parent } \\
\hline Age at first childbirth & 27.8 & 26.5 & 28.3 & 27.3 & 28.1 & 26.9 \\
\hline Years since last childbirth & 15.8 & 15.0 & 14.8 & 14.7 & 17.0 & 15.5 \\
\hline Accumulated number of leave days & 17.22 & 395.67 & 14.21 & 346.96 & 10.53 & 355.45 \\
\hline $\begin{array}{l}\text { Proportion of total leave days in the } \\
\text { household }\end{array}$ & 0.084 & 0.911 & 0.055 & 0.900 & 0.045 & 0.875 \\
\hline \multicolumn{7}{|l|}{ Number of observations } \\
\hline All individuals & 421,066 & 72,660 & 105.137 & 13,162 & 29,755 & 1,740 \\
\hline Parents only & 264,488 & 49,985 & 92,445 & 9,746 & 27,323 & 1,269 \\
\hline
\end{tabular}

All sample means differ significantly (at $1 \%$ ) between men and women, except for values in italics. (Satterthwaites test for equality). Italics indicate that sample means are not different for males and females. 
Table 7. Marginal Effects on Promotion Probability of Alternative Child-Related Variables. Firm-Specific RE-IV Estimator. 1997-2007.

\begin{tabular}{|c|c|c|c|c|}
\hline & \multicolumn{2}{|c|}{ Promotion I (VP) } & \multicolumn{2}{|c|}{ Promotion II (CEO) } \\
\hline & $\begin{array}{l}\text { Main } \\
\text { effect }\end{array}$ & $\begin{array}{c}\text { Interaction } \\
\text { effect }\end{array}$ & $\begin{array}{l}\text { Main } \\
\text { effect }\end{array}$ & $\begin{array}{c}\text { Interaction } \\
\text { effect }\end{array}$ \\
\hline \multicolumn{5}{|l|}{ Model $i$} \\
\hline Woman dummy $(0 / 1)$ & $-0.0013^{* *}$ & - & $-0.0204^{* * * *} *$ & - \\
\hline Ever on maternity or parental leave $(0 / 1)$ & $-0.0008^{* *}$ & $0.0023^{*}$ 冰水 & -0.0021 & 0.0105 \\
\hline \multicolumn{5}{|l|}{ Model ii } \\
\hline Woman dummy $(0 / 1)$ & $-0.0012^{* *}$ & - & -0.0198 *水* & 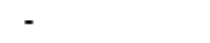 \\
\hline Accumulated number of leave days $/ 100$ & 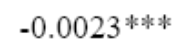 & $0.0024^{* * * *}$ & -0.0202 *水水 & $0.0196^{* * * *}$ \\
\hline \multicolumn{5}{|l|}{ Model iii } \\
\hline Woman dummy $(0 / 1)$ & $-0.0012^{* * *}$ & - & $-0.0193^{\text {*水水 }}$ & - \\
\hline Proportion of total leave days in the household & $-0.0034^{* * *} \cdot k^{2}$ & $0.0042^{*} * k_{*}$ & -0.0053 & 0.0036 \\
\hline \multicolumn{5}{|l|}{ Model iv } \\
\hline Woman dummy $(0 / 1)$ & -0.0007 & - & $-0.0157^{*}$ *水水 & - \\
\hline Age at first childbirth/100 & $0.0094^{*} * k^{*}$ & -0.0027 & 0.0148 & $-0.0602^{* * *}$ \\
\hline \multicolumn{5}{|l|}{ Modelv } \\
\hline Woman dummy $(0 / 1)$ & $-0.0010^{*}$ & - & $-0.0185^{* * *} *$ & - \\
\hline Years since last childbirth/100 & $-0.0117^{* * *} *$ & -0.0013 & -0.0146 & 0.0156 \\
\hline \multicolumn{5}{|l|}{ Other explanatory variables in each model } \\
\hline See Table 5 & Yes & & Yes & \\
\hline & 432,685 & & 113,302 & \\
\hline
\end{tabular}

*) significant at $10 \%, * *$ significant at $5 \%, * *$ significant at $1 \%$ 
Table 8. Estimates of $\delta$ in 7 Alternative Models ('Female-Led' and 'Male-Led' Variables). Firm-Specific RE-IV Estimator. 1997-2007.

\begin{tabular}{|c|c|c|c|}
\hline & $\begin{array}{l}\text { Additional variables } \\
\text { added to model in Table } 5\end{array}$ & $\begin{array}{l}\text { Promotion I } \\
\text { (VP) }\end{array}$ & $\begin{array}{l}\text { Promotion II } \\
(\mathrm{CEO})\end{array}$ \\
\hline Model $i^{1)}$ & $\begin{array}{l}\text { Male CEO with CEO/VP partner }(0 / 1) \\
\text { Male CEO with no partner }(0 / 1) \\
\text { Female CEO }(0 / 1)\end{array}$ & $-0.0011^{*}$ & $\begin{array}{c}-0.0120^{* * * *} \cdot{ }^{2} \\
\mathrm{M}\end{array}$ \\
\hline Model $i i^{2)}$ & $\begin{array}{l}\text { Male CEO with adult daughter }(0 / 1) \\
\text { Female CEO }(0 / 1)\end{array}$ & $-0.0010^{*}$ & $-0.0196^{\text {水水 }}$ \\
\hline Model iii & Female share of VPs and CEOs & -0.0009 & -0.0149 *k* \\
\hline Model iv & Female share of POPs & -0.0004 & -0.0192 *k* \\
\hline Model $v$ & Female Chairman of Board of Directors $(0 / 1)$ & $-0.0011^{* *}$ & $-0.0193^{\text {冰水 }}$ \\
\hline Model $v i$ & $\begin{array}{l}\text { Gap between CEO compensation and average VP } \\
\text { compensation } / 100,000\end{array}$ & $-0.0029 * * *$ & -0.0182 *** \\
\hline \multirow[t]{2}{*}{ Model vii } & Total number of VP & $-0.0024^{* * * *}$ & $-0.0197^{* * * k}$ \\
\hline & Number of observations (all models) & 432,685 & 113,302 \\
\hline
\end{tabular}

1) Excluded category is companies with male CEO married to a partner who is not CEO or VP.

2) Adult daughter is defined as a daughter older than 25. Excluded category is companies with male CEO with no adult daughters.

*) significant at $10 \%, * *$ significant at $5 \%, * * *$ significant at $1 \%$ 
Table 9. Marginal Effects on Promotion Probabilities. 'Overall' Model. Firm-Specific RE-IV Estimator. 1997-2007.

\begin{tabular}{|c|c|c|c|c|}
\hline & \multicolumn{2}{|c|}{ Promotion I (VP) } & \multicolumn{2}{|c|}{ Promotion II (CEO) } \\
\hline & Main effect & $\begin{array}{c}\text { Interaction } \\
\text { effect Woman }\end{array}$ & Main effect & $\begin{array}{c}\text { Interaction } \\
\text { effect Woman }\end{array}$ \\
\hline Woman dummy $(0 / 1)$ & -0.0002 & - & $-0.0113^{*}$ & - \\
\hline 1 child $(0 / 1)$ & $0.0015^{* k * k}$ & $-0.0021 * * *$ & 0.0001 & -0.0030 \\
\hline 2 children $(0 / 1)$ & $0.0024^{* * * *}$ & $-0.0023^{* 2 * *}$ & 0.0018 & -0.0001 \\
\hline $3+$ children $(0 / 1)$ & $0.0030^{\text {*kl }}$ & 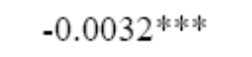 & 0.0029 & -0.0002 \\
\hline Spouse_CEO $(0 / 1)$ & $0.0028 * * *$ & $-0.0017^{* * * *}$ & $0.0123^{* *}$ & -0.0015 \\
\hline Spouse_not_CEO $(0 / 1)$ & $0.0021^{\text {*k* }}$ & $-0.0018^{* * 2 * k}$ & $0.0048^{*}$ 水水 & -0.0054 \\
\hline Accumulated number of leave days $/ 100$ & $-0.0026^{\text {*k } k^{2} *}$ & $0.0026^{* k *}$ & $-0.0207 * * *$ & $0.0204^{* k * k}$ \\
\hline Age at first childbirth/100 & $0.0102^{* * *}$ & -0.0030 & 0.0221 & $-0.0563^{* *}$ \\
\hline Female share of VPs and CEOs & $0.0019 * *$ & -0.0010 & $0.0183^{*} *$ & $-0.0264 * *$ \\
\hline Female chairman $(0 / 1)$ & $-0.0017^{\text {*水水 }}$ & $0.0041^{*}$ & 0.0054 & -0.0044 \\
\hline Female share of POPs & $-0.0043^{*}$ * $k^{*}$ & $-0.0027^{* *} *$ & $-0.0173^{*} * * *$ & -0.0030 \\
\hline Other explanatory variables ${ }^{1)}$ & Yes & & Yes & \\
\hline Number of observations & 432,685 & & 113,302 & \\
\hline
\end{tabular}

*) significant at 10\%, ** significant at 5\%, *** significant at $1 \%$

Note 1 . See Table 5, Note 1. 
Table A1. Promotion Rates by Gender and Year

\begin{tabular}{|c|c|c|c|c|c|c|}
\hline & \multicolumn{6}{|c|}{ Promotion I: POP to VP } \\
\hline & & Males & & & Females & \\
\hline & Stock of POP & $\begin{array}{l}\text { Promotion I } \\
\text { (obs.) }\end{array}$ & $\begin{array}{c}\text { Promotion I } \\
(\%)\end{array}$ & Stock of POP & $\begin{array}{l}\text { Promotion I } \\
\text { (obs.) }\end{array}$ & $\begin{array}{c}\text { Promotion I } \\
(\%)\end{array}$ \\
\hline 1996 & 44,285 & & & 5,658 & & \\
\hline 1997 & 45,281 & 1,230 & $2.8 \%$ & 5,815 & 120 & $2.1 \%$ \\
\hline 1998 & 46,237 & 1,507 & $3.3 \%$ & 6,275 & 142 & $2.4 \%$ \\
\hline 1999 & 43,859 & 2,327 & $5.0 \%$ & 6,208 & 270 & $4.3 \%$ \\
\hline 2000 & 33,668 & 1,886 & $4.3 \%$ & 5,616 & 232 & $3.7 \%$ \\
\hline 2001 & 34,911 & 1,287 & $3.8 \%$ & 6,096 & 154 & $2.7 \%$ \\
\hline 2002 & 34,994 & 1,173 & $3.4 \%$ & 5,929 & 178 & $2.9 \%$ \\
\hline 2003 & 39,231 & 965 & $2.8 \%$ & 6,553 & 137 & $2.3 \%$ \\
\hline 2004 & 36,554 & 1,278 & $3.3 \%$ & 6,802 & 175 & $2.7 \%$ \\
\hline 2005 & 35,627 & 1,410 & $3.9 \%$ & 7,336 & 264 & $3.9 \%$ \\
\hline 2006 & 34,937 & 1,653 & $4.6 \%$ & 7,598 & 283 & $3.9 \%$ \\
\hline \multirow[t]{3}{*}{2007} & & 1,622 & $4.6 \%$ & & 274 & $3.6 \%$ \\
\hline & \multicolumn{6}{|c|}{ Promotion II: VP to CEO } \\
\hline & Stock of VP & $\begin{array}{c}\text { Males } \\
\text { Promotion II } \\
\text { (obs.) }\end{array}$ & $\begin{array}{c}\text { Promotion II } \\
(\%)\end{array}$ & Stock of VP & $\begin{array}{l}\text { Females } \\
\text { Promotion II } \\
\text { (obs.) }\end{array}$ & $\begin{array}{c}\text { Promotion II } \\
(\%)\end{array}$ \\
\hline 1996 & 9,471 & & & 867 & & \\
\hline 1997 & 9,566 & 327 & $3,5 \%$ & 885 & 20 & $2.3 \%$ \\
\hline 1998 & 9,727 & 360 & $3.8 \%$ & 927 & 16 & $1.8 \%$ \\
\hline 1999 & 10,154 & 371 & $3.8 \%$ & 1,071 & 17 & $1.8 \%$ \\
\hline 2000 & 9,984 & 453 & $4.5 \%$ & 1,184 & 32 & $3.0 \%$ \\
\hline 2001 & 9,842 & 422 & $4.2 \%$ & 1,122 & 37 & $3.1 \%$ \\
\hline 2002 & 8,783 & 369 & $3.7 \%$ & 1,100 & 20 & $1.8 \%$ \\
\hline 2003 & 8,681 & 315 & $3.6 \%$ & 1,129 & 17 & $1.5 \%$ \\
\hline 2004 & 9,222 & 337 & $3.9 \%$ & 1,254 & 21 & $1.9 \%$ \\
\hline 2005 & 9,407 & 387 & $4.2 \%$ & 1,413 & 33 & $2.6 \%$ \\
\hline 2006 & 9,585 & 368 & $3.9 \%$ & 1,459 & 39 & $2.8 \%$ \\
\hline 2007 & & 422 & $4.4 \%$ & & 39 & $2.7 \%$ \\
\hline
\end{tabular}


Table A2. Sample Means for Selected Variables.2007.

By Gender and Occupational Position ${ }^{l)}$.

\begin{tabular}{|c|c|c|c|c|c|c|}
\hline & \multicolumn{2}{|c|}{ POP } & \multicolumn{2}{|c|}{ VP } & \multicolumn{2}{|c|}{$\mathrm{CEO}$} \\
\hline & Males & Females & Males & Females & Males & Females \\
\hline \multicolumn{7}{|l|}{ Individual characteristics } \\
\hline Short further education $(0 / 1)$ & $\begin{array}{c}0.07 \\
(0.25)\end{array}$ & $\begin{array}{c}0.09 \\
(0.29)\end{array}$ & $\begin{array}{c}0.08 \\
(0.28)\end{array}$ & $\begin{array}{c}0.11 \\
(0.31)\end{array}$ & $\begin{array}{c}0.05 \\
(0.23)\end{array}$ & $\begin{array}{c}0.06 \\
(0.24)\end{array}$ \\
\hline Medium further education $(0 / 1)$ & $\begin{array}{l}0.16 \\
(0.37)\end{array}$ & $\begin{array}{c}0.15 \\
(0.36)\end{array}$ & $\begin{array}{c}0.26 \\
(0.44)\end{array}$ & $\begin{array}{c}0.20 \\
(0.40)\end{array}$ & $\begin{array}{c}0.28 \\
(0.45)\end{array}$ & $\begin{array}{c}0.21 \\
(0.41)\end{array}$ \\
\hline Long further education $(0 / 1)$ & $\begin{array}{c}0.11 \\
(0.31)\end{array}$ & $\begin{array}{c}0.15 \\
(0.36)\end{array}$ & $\begin{array}{c}0.20 \\
(0.40)\end{array}$ & $\begin{array}{c}0.23 \\
(0.42)\end{array}$ & $\begin{array}{c}0.21 \\
(0.41)\end{array}$ & $\begin{array}{c}0.24 \\
(0.43)\end{array}$ \\
\hline Work experience, years & $\begin{array}{c}18.90 \\
(12.02)\end{array}$ & $\begin{array}{c}17.23 \\
(10.40)\end{array}$ & $\begin{array}{l}23.41 \\
(9.79)\end{array}$ & $\begin{array}{l}20.70 \\
(9.41)\end{array}$ & $\begin{array}{c}24.35 \\
(10.05)\end{array}$ & $\begin{array}{l}19.70 \\
(9.08)\end{array}$ \\
\hline Tenure, years & $\begin{array}{c}4.76 \\
(6.89)\end{array}$ & $\begin{array}{c}4.34 \\
(6.12)\end{array}$ & $\begin{array}{c}6.64 \\
(7.22)\end{array}$ & $\begin{array}{c}6.12 \\
(7.04)\end{array}$ & $\begin{array}{l}8.23 \\
(7.91)\end{array}$ & $\begin{array}{c}5.66 \\
(6.78)\end{array}$ \\
\hline Age, years & $\begin{array}{c}41.36 \\
(13.00)\end{array}$ & $\begin{array}{c}40.60 \\
(10.91)\end{array}$ & $\begin{array}{l}46.35 \\
(8.64)\end{array}$ & $\begin{array}{l}43.80 \\
(8.44)\end{array}$ & $\begin{array}{l}49.17 \\
(8.85)\end{array}$ & $\begin{array}{l}44.14 \\
(9.30)\end{array}$ \\
\hline \multicolumn{7}{|l|}{ Firm characteristics ${ }^{2}$} \\
\hline Less than 50 employees $(0 / 1)$ & $\begin{array}{c}0.42 \\
(0.49)\end{array}$ & $\begin{array}{c}0.34 \\
(0.47)\end{array}$ & - & - & - & - \\
\hline 50-100 employees $(0 / 1)$ & $\begin{array}{c}0.03 \\
(0.17)\end{array}$ & $\begin{array}{c}0.05 \\
(0.21)\end{array}$ & $\begin{array}{c}0.32 \\
(0.47)\end{array}$ & $\begin{array}{c}0.41 \\
(0.49)\end{array}$ & $\begin{array}{c}0.50 \\
(0.50)\end{array}$ & $\begin{array}{c}0.53 \\
(0.50)\end{array}$ \\
\hline $101-500$ employees $(0 / 1)$ & $\begin{array}{c}0.11 \\
(0.31)\end{array}$ & $\begin{array}{c}0.16 \\
(0.37)\end{array}$ & $\begin{array}{c}0.47 \\
(0.50)\end{array}$ & $\begin{array}{c}0.45 \\
(0.50)\end{array}$ & $\begin{array}{c}0.41 \\
(0.49)\end{array}$ & $\begin{array}{c}0.41 \\
(0.49)\end{array}$ \\
\hline More than 500 employees $(0 / 1)$ & $\begin{array}{c}0.44 \\
(0.50)\end{array}$ & $\begin{array}{c}0.45 \\
(0.50)\end{array}$ & $\begin{array}{c}0.21 \\
(0.41)\end{array}$ & $\begin{array}{c}0.13 \\
(0.34)\end{array}$ & $\begin{array}{c}0.09 \\
(0.28)\end{array}$ & $\begin{array}{c}0.05 \\
(0.22)\end{array}$ \\
\hline Listed on stock exchange $(0 / 1)$ & $\begin{array}{c}0.03 \\
(0.18)\end{array}$ & $\begin{array}{c}0.05 \\
(0.22)\end{array}$ & $\begin{array}{c}0.06 \\
(0.23)\end{array}$ & $\begin{array}{l}0.05 \\
(0.21)\end{array}$ & $\begin{array}{c}0.03 \\
(0.17)\end{array}$ & $\begin{array}{c}0.01 \\
(0.11)\end{array}$ \\
\hline Lagged performance (ROE) & $\begin{array}{c}1.19 \\
(115.37)\end{array}$ & $\begin{array}{c}-0.09 \\
(25.72)\end{array}$ & $\begin{array}{c}0.22 \\
(4.73)\end{array}$ & $\begin{array}{c}0.28 \\
(3.23)\end{array}$ & $\begin{array}{c}0.16 \\
(4.32)\end{array}$ & $\begin{array}{l}0.05 \\
(4.01)\end{array}$ \\
\hline Female share of employees & $\begin{array}{c}0.29 \\
(0.20)\end{array}$ & $\begin{array}{c}0.47 \\
(0.23)\end{array}$ & $\begin{array}{c}0.33 \\
(0.18)\end{array}$ & $\begin{array}{c}0.49 \\
(0.22)\end{array}$ & $\begin{array}{c}0.32 \\
(0.21)\end{array}$ & $\begin{array}{c}0.50 \\
(0.26)\end{array}$ \\
\hline Number of observations & 34,765 & 8,328 & 9,934 & 1,552 & 2,824 & 229 \\
\hline
\end{tabular}

1) Satterthwaites test for equality between males and females shows that all variable means are significantly different for men and women, except for values in italics.

2) Firm size variables refer to origin company in cases where executives change company. In the estimation we include lagged values for both recruiting and origin company.

Table A3. Marginal Effects on Promotion Probability: Experience variables and Tenure interacted by Gender. Firm-Specific RE-IV Estimator. 1997-2007.

\begin{tabular}{|c|c|c|c|c|}
\hline & \multicolumn{2}{|c|}{ Promotion I (VP) } & \multicolumn{2}{|c|}{ Promotion II (CEO) } \\
\hline & Main effect & $\begin{array}{c}\text { Interaction } \\
\text { effect Woman }\end{array}$ & Main effect & $\begin{array}{l}\text { Interaction } \\
\text { effect Woman }\end{array}$ \\
\hline Woman dummy (0/1) & $-0.0035 * * *$ & - & $-0.0251^{*} * *$ & - \\
\hline Tenure & $-0.0001^{* * * *}$ & $0.0001^{*}$ & 0.0000 & -0.0006 \\
\hline Experience before POP & $-0.0011^{* * *}$ & 0.0000 & $-0.0174^{*} * * 2$ & $0.0008 *$ \\
\hline Experience as POP & $-0.0015^{* * *} *$ & 0.0000 & $-0.0173^{* * * *}$ & -0.0006 \\
\hline Experience as VP & - & - & $-0.0173^{*} * *$ & 0.0012 \\
\hline \multicolumn{5}{|l|}{ Other explanatory variables } \\
\hline See basic model, Table 2 & Yes & Yes & Yes & Yes \\
\hline Number of observations & 432,685 & 432,685 & 113,302 & 113,302 \\
\hline
\end{tabular}

$*$ ) significant at $10 \%, * *$ significant at $5 \%, * * *$ significant at $1 \%$ 
Table A4. Age at First Childbirth, Conditional on Occupational Position in 2007.

\begin{tabular}{lcccccc}
\hline & \multicolumn{2}{c}{ POP } & \multicolumn{2}{c}{ VP } & \multicolumn{2}{c}{ CEO } \\
& Males & Females & Males & Females & Males & Females \\
\hline 0 children & $31.88 \%$ & $30.74 \%$ & $11.22 \%$ & $24.55 \%$ & $8.14 \%$ & $25,33 \%$ \\
At least 1 child, age at first birth: & & & & & & \\
-21 & $1,73 \%$ & $4,45 \%$ & $1.73 \%$ & $3.03 \%$ & $1.95 \%$ & $3,06 \%$ \\
$21-22$ & $3,71 \%$ & $6,05 \%$ & $3.84 \%$ & $6.19 \%$ & $3.97 \%$ & $6,99 \%$ \\
$23-24$ & $7.33 \%$ & $8,90 \%$ & $8.21 \%$ & $6.83 \%$ & $9.31 \%$ & $10,92 \%$ \\
$25-26$ & $10.80 \%$ & $10.85 \%$ & $12.75 \%$ & $10.05 \%$ & $13.88 \%$ & $11,35 \%$ \\
$27-28$ & $12.15 \%$ & $11,23 \%$ & $16.51 \%$ & $13.60 \%$ & $15.58 \%$ & $9,61 \%$ \\
$29-30$ & $11.44 \%$ & $10.71 \%$ & $15.65 \%$ & $12.89 \%$ & $17,53 \%$ & $10,92 \%$ \\
$30+$ & $20.96 \%$ & $17.06 \%$ & $30.06 \%$ & $22.87 \%$ & $29.64 \%$ & $21,83 \%$ \\
& & & & & & \\
Total & $100 \%$ & $100 \%$ & $100 \%$ & $100 \%$ & $100 \%$ & $100 \%$ \\
Number of observations & 34,765 & 8,328 & 9,934 & 1.552 & 2,824 & 229 \\
\hline
\end{tabular}


Table A5: Sample means of variables reflecting both 'female-led firms' and 'male-led firms' by gender. 1996-2007. ${ }^{1}$

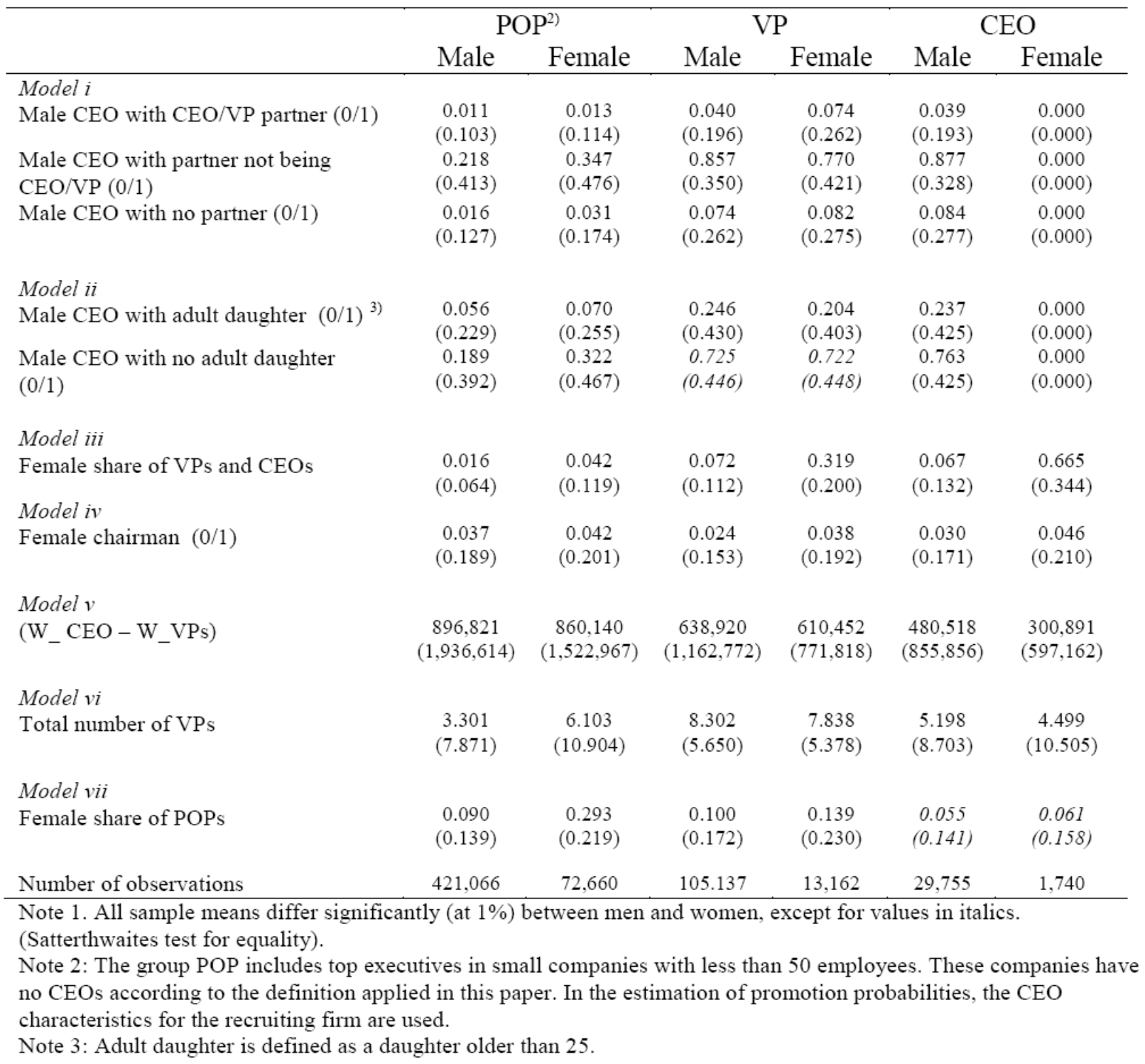

